NBER WORKING PAPER SERIES

\title{
THE (HETEROGENOUS) ECONOMIC EFFECTS OF PRIVATE EQUITY BUYOUTS
}

\author{
Steven J. Davis \\ John C. Haltiwanger \\ Kyle Handley \\ Ben Lipsius \\ Josh Lerner \\ Javier Miranda \\ Working Paper 26371 \\ http://www.nber.org/papers/w26371 \\ NATIONAL BUREAU OF ECONOMIC RESEARCH \\ 1050 Massachusetts Aenue \\ Cambridge, MA 02138 \\ October 2019, Revised July 2021
}

Davis, Haltiwanger, Handley, and Lerner are affiliates of the National Bureau of Economic Research. Haltiwanger was also a part-time Schedule A employee and Javier Miranda was an employee at the U.S. Census Bureau during the preparation of this paper. We thank Edie Hotchkiss (discussant), Ron Jarmin, Steve Kaplan, Ann Leamon, Antoinette Schoar (discussant), and Kirk White for helpful comments, as well as seminar participants at the 2019 American Economic Association annual meeting, Carnegie-Mellon University, Georgia Tech, Harvard Law School, the Hoover Institution, Michigan Ross, MIT, the NBER Productivity Lunch Group, and the 2020 Western Finance Association meetings. We thank Christine Rivera, Kathleen Ryan and James Zeitler of Harvard Business School's Baker Library for their assistance, as well as Andrea Barreto, Franko Jira, Cameron Khansarinia, Ayomide Opeyemi, Steven Moon, and Yuan Sun. Special thanks are due to Francisca Rebelo for her help with revisions. Per Stromberg generously gave permission to use older transaction data collected as part of a World Economic Forum project. We thank the Harvard Business School's Division of Research, the Private Capital Research Institute, the Ewing Marion Kauffman Foundation, and especially the Smith Richardson Foundation for generous research support. Opinions and conclusions expressed herein are the authors and do not necessarily represent the views of the U.S. Census Bureau. All results have been reviewed to ensure that no confidential information is disclosed (DRB-B0109-CDAR-2018718, DRB-B0110- CDAR-2018-0718, DRBB0020-CED-20181128， DRB-B0018-CED-20181126， CBDRB-FY19- CMS-8034, and CBDRB-FY21-CED006-0017). Lerner has advised institutional investors in private equity funds, private equity groups, and governments designing policies relevant to private equity. Davis has served as an expert witness in a legal dispute between private equity firms. All errors and omissions are our own. The views expressed herein are those of the authors and do not necessarily reflect the views of the National Bureau of Economic Research.

At least one co-author has disclosed additional relationships of potential relevance for this research. Further information is available online at http://www.nber.org/papers/w26371.ack

NBER working papers are circulated for discussion and comment purposes. They have not been peer-reviewed or been subject to the review by the NBER Board of Directors that accompanies official NBER publications.

(C) 2019 by Steven J. Davis, John C. Haltiwanger, Kyle Handley, Ben Lipsius, Josh Lerner, and Javier Miranda. All rights reserved. Short sections of text, not to exceed two paragraphs, may be quoted without explicit permission provided that full credit, including (C) notice, is given to the source. 
The (Heterogenous) Economic Effects of Private Equity Buyouts

Steven J. Davis, John C. Haltiwanger, Kyle Handley, Ben Lipsius, Josh Lerner, and Javier

Miranda

NBER Working Paper No. 26371

October 2019, Revised July 2021

JEL No. D22,D24,G24,G34,J63,L25

\section{ABSTRACT}

The effects of private equity buyouts on employment, productivity, and job reallocation vary tremendously with macroeconomic and credit conditions, across private equity groups, and by type of buyout. We reach this conclusion by examining the most extensive database of U.S. buyouts ever compiled, encompassing thousands of buyout targets from 1980 to 2013 and millions of control firms. Employment shrinks $13 \%$ over two years after buyouts of publicly listed firms - on average, and relative to control firms - but expands $13 \%$ after buyouts of privately held firms. Post-buyout productivity gains at target firms are large on average and much larger yet for deals executed amidst tight credit conditions. A post-buyout tightening of credit conditions or slowing of GDP growth curtails employment growth and intra-firm job reallocation at target firms. We also show that buyout effects differ across the private equity groups that sponsor buyouts, and these differences persist over time at the group level. Rapid upscaling in deal flow at the group level brings lower employment growth at target firms.

Steven J. Davis

Booth School of Business

The University of Chicago

5807 South Woodlawn Avenue

Chicago, IL 60637

and NBER

Steven.Davis@ChicagoBooth.edu

John C. Haltiwanger

Department of Economics

University of Maryland

College Park, MD 20742

and NBER

haltiwan@econ.umd.edu

Kyle Handley

University of California, San Diego

School of Global Policy and Strategy

La Jolla, CA 92093

and NBER

khandley@ucsd.edu
Ben Lipsius

University of Michigan

618 South Main Street, Apt 512

Ann Arbor, MI 48104

blipsius@umich.edu

Josh Lerner

Harvard Business School

Rock Center 214

Soldiers Field

Boston, MA 02163

and NBER

jlerner@hbs.edu

Javier Miranda

Kleine MaerkerstraÃ Ÿe 8

Halle (Saale), Saxo D-06108

Germany

and Halle Institute for Economic Research

javier.miranda@uni-jena.de 
This paper develops evidence of a remarkable heterogeneity in the economic effects of private equity (PE) buyouts. Specifically, the effects on employment, job reallocation, and productivity differ markedly by type of buyout, with credit conditions that prevail when the buyout closes, with the evolution of macroeconomic and credit conditions after the buyout, and across the PE groups that sponsor buyouts. To carry out our study, we tap multiple sources to identify and characterize about 9,800 PE buyouts of U.S. firms from 1980 to 2013. For roughly 6,000, we successfully merge information about the buyout with comprehensive Census micro data on firmlevel and establishment-level outcomes. Armed with this database, we estimate the effects of buyouts on target firms relative to contemporaneous developments at comparable firms not backed by private equity. We focus on outcomes over the first two years after the buyout.

Our large sample, long time period, high-quality data, and ability to track firms and establishments enable a careful look at heterogeneity in the real-side effects of buyouts. We can, for example, investigate how buyout effects on independent, privately held firms compare to those of publicly listed firms. Because our sample period encompasses huge swings in credit market tightness and macroeconomic performance, we can address recurring questions about how these external conditions affect the relative performance of target firms. By tracking individual PE groups over time, we can assess whether they differ in their impact on target firms, and whether and how much those differences persist over time.

Our chief findings include the following:

- Post-buyout labor productivity gains at target firms are large relative to contemporaneous outcomes at control firms, and much larger yet for deals executed in tight credit conditions.

- Relative employment at targets rises 13 percent, on average, in firms previously under private ownership, whereas it falls 13 percent in buyouts of publicly listed firms. 
- A post-buyout widening of credit spreads, or a slowdown in GDP growth, lowers employment growth and intra-firm job reallocation at targets (again, relative to controls).

- The mix of buyout types and PE sponsor characteristics varies over time, but there is little evidence that changes in this mix drive the sensitivity of buyout effects to market conditions.

- Buyout effects on employment differ among the PE groups that sponsor buyouts, and these differences persist over time at the group level. ${ }^{2}$

- Rapid upscaling in deal flow at the PE group level brings weaker post-buyout employment performance at target firms, conditional on the group's performance history, time effects, and a battery of other controls.

In short, the real-side effects of buyouts on target firms are more complex and varied than either PE champions or detractors claim. Indeed, the effects are highly circumstance-specific in a manner, we argue, that aligns well with financial theory and with evidence on the financial performance of PE buyouts.

Our study builds on and draws inspiration from many previous works. Early studies on the real-side outcomes associated with PE buyouts include Kaplan (1989) and Lichtenberg and Siegel (1990). More recent research considers larger samples, often by exploiting a combination of proprietary and government data sources. Examples include Boucly, Sraer, and Thesmar (2011), Cohn, Mills, and Towery (2014), Davis et al. (2014), Farcassi, Previtero, and Sheen (2018), and Cohn, Nestoriak, and Wardlaw (2019). Beginning with Bernstein and Sheen (2016), many recent studies consider the impact of private equity in particular industry settings. Relative to Davis et al.

${ }^{2}$ Echoing persistent financial performance differences at the group level (e.g., Kaplan and Schoar, 2005, and Harris et al., 2020). Unlike the case of financial performance, however, we see no evidence of a weakening over time in the group-level persistence of real-side effects. 
(2014), we improve on their empirical methods, extend their sample period to cover the financial crisis and its aftermath, draw on previous research to explain why we anticipate heterogeneity in the real-side effects of PE buyouts, and provide a rich set of new findings on how buyout effects vary with macroeconomic and credit conditions, by type of buyout, across the PE groups that sponsor buyouts, and with the scale of buyout activity at the group level. Below, we offer many additional remarks about how our study and findings relate to previous research.

The next section reviews theoretical perspectives and prior empirical research that help understand the heterogenous effects of PE buyouts. Section II discusses the creation of our database. Section III sets forth our empirical approach and describes our results. Section IV concludes the paper. Appendices provide additional information about our data and empirical methods and additional results.

\section{Sources of Heterogeneity in the Effects of Private Equity Buyouts}

There are several theoretical reasons to anticipate heterogeneity in the real-side economic impact of various buyouts. ${ }^{3}$ This section reviews some of the key literature to help frame the analyses that follow.

\section{A. Differences across Buyout Types}

There is little theoretical work on the heterogeneous effects of PE buyouts per se, but the tradeoffs between publicly traded and privately held ownership are the subject of an extensive literature. Among the hypothesized advantages of public ownership are lower equity costs, higher firm values, and relaxed capital constraints. Zingales (1995), for instance, hypothesizes that public listings put firms "on the radar screen" of potential acquirers and, under certain conditions,

\footnotetext{
3 The main text focuses on productivity, employment and job reallocation effects. Appendix D also presents estimated buyout effects on firm-level mean wages, which appear to be heavily influenced by buyout-related shifts in management compensation.
} 
maximize firm value. Pagano et al. (1998) argue that access to public equity markets reduces the cost of credit by giving firms more bargaining power with their banks, thereby maximizing capital availability and enhancing firm value. Chemmanur and Fulghieri (1999) suggest that private investors may demand a risk premium, and value firms accordingly. Brau et al. (2003) argue that IPOs create publicly traded shares that a firm can use as "currency" when acquiring other companies. Maksimovic and Pichler (2001) model firms that conduct IPOs to increase publicity or reputation value, thereby improving capital market access and raising firm value.

Being publicly traded also comes at a cost. The vulnerability of publicly traded firms to agency problems has been understood since Jensen and Meckling (1976). Due to weaknesses in the market for corporate control, difficulties in monitoring by dispersed shareholders, problematic incentives of corporate directors, compensation schemes that reward empire building and myriad other reasons, publicly traded firms can be especially prone to value-destroying activities. Jensen (1989) proposed that buyouts are optimized to resolve these problems. Axelson et al. (2013) report that buyouts of publicly traded firms are more associated with high debt burdens, which Jensen hypothesized create pressure on management to take cost-cutting steps they might otherwise resist.

These arguments and observations suggest that the consequences of PE buyouts differ between publicly traded and privately held targets. For targets that trade publicly before the buyout, PE groups may focus on tackling the agency problems sketched above - whether manifested as excess headcounts, wasteful perquisites, or value-destroying "pet projects." ${ }^{\text {F }}$ For

\footnotetext{
${ }^{4}$ Job losses after public-to-private and divisional buyouts could also be interpreted along the lines of the workforce re-contracting hypothesis that Shleifer and Summers (1988) advance in the context of hostile corporate takeovers. They stress the role of implicit long-term contracts in fostering relationship-specific investments by the firm's stakeholders. According to the recontracting hypothesis, takeovers that break implicit contracts can be profitable for shareholders, at least in the short run.
} 
privately held targets that face fewer agency problems but find it harder to access capital markets, it makes sense for PE groups to devote greater attention to investments that drive growth. Insofar as PE buyouts lead to productivity gains at target firms, these observations also suggest that the mechanisms at work may be quite different for publicly listed and privately held targets.

Case evidence illustrates some of these points. In late 1987, Berkshire Partners bought out the Lake States Transportation division of the Soo Line (the U.S. subsidiary of the publicly traded Canadian Pacific), renaming it Wisconsin Central. The new management cut operating employees per train from 4.8 to 2.2 and cut wages by $15 \% .{ }^{5}$ As a result, labor costs dropped from the historical $50 \%$ of revenue to $32 \%$ in 1988 . In later years, Wisconsin Central continued to improve labor productivity through the application of better information technology and tight management, with revenue ton-miles per workhour rising 54\% from 1989 to 1995 (Jensen, Burkhardt and Barry, 1989, and SEC filings). ${ }^{6}$ In another case, Brazos Partners acquired $80 \%$ of privately held Cheddar's Restaurants in 2003, buying out many "friends and family" investors who were reluctant to put additional capital into the firm. Brazos' own funds, its banking connections, and its industry relationships enabled the firm to greatly accelerate its pace of restaurant openings, bring in new managers to rationalize the practices of an extremely informal organization, and develop new chain concepts. The founder, having liquidated much of his equity in the firm and diversifying his asset holdings, still retained a significant equity stake but nonetheless became more willing to pursue high-risk, high expected-return strategies (Hardymon and Leamon, 2006).

Existing empirical work also finds evidence consistent with these hypotheses. For instance, Boucly, Sraer, and Thesmar (2011) analyze a sample of largely private-to-private buyouts of

\footnotetext{
${ }^{5}$ Most of the division's employees opted to remain with Soo Line, as the new owners made clear that transferred employees would lose seniority rights and work in a non-union environment. ${ }^{6}$ Jensen, Burkhardt, and Barry (1989) and SEC filings.
} 
French firms. They conclude that these buyouts eased financing constraints at target firms, enabling their expansion. Large productivity gains fit well with evidence in Bloom, Sadun, and van Reenen (2015), who survey a sample of buyouts of middle-market firms, where private-toprivate deals predominated. They find that these PE deals led to investments that resulted in better management practices. Hellman and Puri (2002) provide evidence that venture capital helped drive the professionalization of recruitment, human resource policies, marketing, and the use of stock options in high-tech start-up firms. Similarly, private equity may drive professionalization in the buyouts of privately held firms in particular, especially when sales growth or market conditions have outpaced legacy management structures and processes.

\section{B. Differences over the Economic Cycle}

Axelson, Stromberg, and Weisbach (2007) offer a useful framework for understanding why the consequences of buyouts may vary over the economic cycle. ${ }^{7}$ In their setting, privatelyinformed firms (e.g., the general partners of PE groups) raise funds from less-informed investors. Informational asymmetries create a temptation on the part of general partners to overstate the potential of their investments. Axelson et al. show that the (second-best) solution ties the compensation of PE investors to the collective performance of a fund, rather than that of individual

7 More generally, fluctuations in credit availability have long pre-occupied economists (e.g., Kindleberger, 1978). One concern involves the incentives that drive credit decisions. In Rajan's (1994) model, for example, the desire to manage short-term earnings drives bankers to make valuedestroying loans in good times and curtail lending abruptly in bad times. A second concern involves the banking system's capacity to supply credit. Bernanke and Gertler (1987) develop a theory in which negative shocks to bank capital cause them to forego value-creating loans. A third set of concerns surrounds the effects of credit availability on the broader economy. According to the "financial accelerator" mechanism in leading macro models (e.g., Bernanke, Gertler and Gilchrist, 1999), endogenous swings in credit availability amplify and propagate the effects of shocks to the macroeconomy. Credit availability and debt levels are also a key focus in many post mortems of economic crises (e.g., Reinhart and Rogoff, 2009; Campello, Graham, and Harvey, 2010; and Schularick and Taylor, 2012) and a first-order concern for central bankers. 
buyouts. In this way, the general partners have less incentive to invest in bad deals. Moreover, it makes sense for fund managers to invest equity alongside outside debt raised on a deal-by-deal basis, thus providing a further check on the temptation to do lower-quality deals with funds raised.

Even when employing this optimal financing structure, however, Axelson et al. show that PE groups are tempted to overinvest during hot markets. Conversely, during recessions, valuecreating projects may languish unfinanced. These distortions amplify the normal ebb and flow of the business cycle, resulting in an intense pro-cyclicality of PE deal-making activity.

This theoretical work focuses on the cyclicality of PE activity and the financial returns to buyouts, but it has implications as well for their real-side consequences. In particular, deals done when financing is plentiful may end up underperforming for two reasons. First, due to overfunding, PE groups may move "down their own demand curve" when financing is easy, selecting inferior deals with less scope for value creation in the form of operational improvements. Second, if the supply of experienced PE managers is not fully elastic in the short term, a larger deal flow may dilute the attention paid to any given portfolio company. Both reasons lead to weaker post-buyout operating performance for deals executed amidst easy-credit conditions. While we cannot pin down which of these two reasons (or both) might be at work, this line of thinking says that the marginal benefits of PE buyouts in the form of productivity gains are countercyclical.

The post-buyout evolution of macroeconomic and credit conditions is also likely to affect the performance of target firms. As Appendix Table D.4 shows, firms backed by private equity are far more likely to engage in acquisitions than their peers. To the extent that market conditions influence the ability of target firms to undertake post-buyout acquisitions and divestitures, a deterioration in macroeconomic or credit conditions can affect overall employment growth and reallocation in target firms, although not necessarily the organic parts. 
There is also previous empirical research on the relationship between buyouts and credit cycles. Pioneering work by Kaplan and Stein (1993) presents evidence that fits "a specific version of the overheated buyout market hypothesis... [that] the buyouts of the later 1980s [were] both more aggressively priced and more susceptible to costly financial distress." Twenty-five of 66 deals in their sample executed during the easy-credit period from 1986 to 1988 later underwent a debt default, an attempt to restructure debt, or a Chapter 11 bankruptcy filing. In glaring contrast, only one of 41 deals executed from 1980 to 1984, when credit conditions were much tighter, experienced one of these forms of financial distress. Axelson et al. (2013) look at a broader sample of deals and show that credit market conditions drove leverage in buyouts far more than in publicly listed firms. Kaplan and Schoar (2005), among others, find that easier credit conditions bring greater inflows into buyout funds and lower fund-level returns. ${ }^{8}$ In short, the literature suggests that when economic growth booms and credit spreads narrow, PE funds attract larger inflows, their deals involve more leverage and higher valuations, and investors ultimately receive lower returns. We investigate the impact of these forces on the real-side outcomes at target firms, which has received little attention to date. ${ }^{9}$

Much less is written, from either a theoretical or empirical perspective, about the interaction of buyout type and economic cycles: whether the sensitivity of buyouts to external conditions differs by type of buyout. Nonetheless, we hypothesize that productivity gains and the pace of reallocation are more procyclical in public-to-private than private-to-private deals. Public-

\footnotetext{
${ }^{8}$ Other papers that touch in various ways on market cycles and private equity include Ivashina and Kovner (2011), Hotchkiss, Strömberg, and Smith (2014), Harris, Jenkinson, and Kaplan (2016), and Bernstein, Lerner, and Mezzanotti (2019).

${ }^{9}$ One exception is the survey data in Bernstein, Lerner, and Mezzanotti (2019), which provide evidence that PE groups devoted more attention to the operating performance and strategic decision making of their portfolio companies during the financial crisis of 2008-09.
} 
to-private deals are both more leveraged (Axelson et al. 2013) and more likely to encounter financial distress (Stromberg, 2008). Thus, tight financial conditions during downturns may divert the attention of management at the target firm and the PE group itself away from operating performance. In addition, insofar as the typically larger buyouts of publicly listed firms are more dependent on continuing capital market access (e.g., to finance ongoing acquisitions and divestitures that reshape the firm), economic downturns may especially impair restructuring and performance in public-to-private buyouts.

\section{Differences across Private Equity Groups}

Economists have become increasingly attuned to the role of persistent organizationspecific attributes that affect productivity. Syverson (2011) provides an overview of many key studies, and Autor et al. (2020) examine a related phenomenon. Many differences in firm performance reflect heterogeneity in management practices (Bloom and van Reenen, 2007). Bertrand and Schoar (2003) show that top executives influence firm performance and key strategic choices, an effect that holds even when focusing on switchers who move from one firm to the next.

These differences can manifest across PE groups as well. Practitioner accounts (e.g., Bain, 2020) suggest that PE groups often have well-defined specializations, not just in regard to industry (e.g., the focus of ABRY on telecommunications or Vista on software), but in their approaches to value creation. One frequently encounters claims that some PE groups place greater emphasis on value creation through operational improvements while others stress financial engineering. Anecdotal accounts suggest that PE groups have "playbooks" and shared-value systems, which they apply to their investments in buyout after buyout (Lerner, Tagade, and Shu, 2018, and Wulf and Waggoner, 2010). PE groups are also remarkably stable in terms of their key senior management (Lerner and Noble, 2021), which may drive persistence in their approaches. 
In line with these remarks, Kaplan and Schoar (2005) and Harris et al. (2020) find strong persistence in the financial performance of buyout groups, at least for funds formed through 2000. Thus, in addition to the effects of market cycles and buyout types, we hypothesize the presence of PE group-specific differences in their effects on portfolio firms.

\section{Creating the Leveraged Buyout Sample}

\section{A. Identifying Private Equity Buyouts}

Our study builds on the data work and analysis in Davis et al. (2014) to consider transactions involving later-stage companies with changes in ownership and control, executed and partly financed by PE firms. In these deals, the (lead) PE firm acquires a controlling equity stake in the target firm and retains significant oversight until it exits by selling its stake. The buyout typically involves a shift toward greater leverage in the capital structure of the target firm and, sometimes, a change in its management. Bank loans are key sources of the credit that facilitate the leveraged nature of PE buyouts.

We made major efforts to construct our sample of buyouts and ensure its integrity, expending thousands of research assistant hours. The specific process is described in Appendix A. The resulting sample contains 9,794 PE-led leveraged buyouts of U.S. companies from January 1, 1980 to December 31, 2013. We sort the sample buyouts into four main deal types based on descriptions in CapitalIQ and our reviews of other databases, press accounts, and securities filings.

Figure 1 displays quarterly counts of PE-sponsored buyouts in our sample for the four deal types. ${ }^{10}$ As noted in other studies, PE buyout activity grew enormously in recent decades. The

\footnotetext{
${ }^{10}$ Appendix Table D. 1 reports average quarterly counts before, during and after the financial crisis. Because we lack non-Census data on deal size for much of our sample, especially in more recent years, we cannot construct a size-weighted version of Figure 1 without matching to Census micro data. Once we match, however, we become subject to Census disclosure rules that preclude a granular depiction of deal flow as in Figure 1.
} 
expansion is especially striking for private-to-private buyouts, which saw a huge increase in deal flow over time. The flow of new PE buyouts crashed during the financial crisis, as credit conditions tightened and the economy contracted. Interestingly, the flow of new public-to-private buyouts dropped off well before the onset of the financial crisis, and remained at modest levels through the end of our sample. Counts for private-to-private and secondary (where PE groups are on both sides of the buyout) transactions rebounded sharply as the economy recovered from the 2008-09 recession and maintained a robust pace until the end of our sample in 2013.

To set the stage for the analysis below, Table 1 presents evidence on how deal flow relates to economic and credit conditions. Specifically, we regress the natural log of quarterly buyout counts on buyout type indicators, a linear time trend, and the deal-type indicators interacted with market conditions. We consider conditions when the buyout closed (top panel) and changes over the next two years (bottom panel). We use real GDP growth to characterize economic conditions and the yield spread between below-investment-grade corporate bonds and one-month LIBOR for credit conditions. (See Section III.D for precise definitions.)

The results are striking. The top panel says that deal volumes are higher when real GDP growth is above its sample median and credit spreads are narrower than the median. Buyout counts are $28 \log$ points (32\%) higher for private-to-private deals, $66 \log$ points (93\%) higher for publicto-private deals, and $41 \log$ points $(51 \%)$ higher for divisional sales in periods with above-average GDP growth, conditional on the credit-spread interaction variables and the controls. Buyout counts are 18-27 log points lower when credit spreads are wider than average, conditional on the other regressors. The credit spread results are considerably stronger when using an upper tercile split. (See Appendix Table D.2.) Axelson et al. (2013), among others, also document the relationship of credit spreads to buyout activity and to the extent of leverage and valuations. 
The bottom panel in Table 1 says that periods with high buyout volume are associated with rising credit spreads over the next two years and, except for secondary sales, higher than average GDP growth over the next two years. Again, the associations are large in magnitude. For example, buyout counts are 20-68 log points higher in periods that precede above-average increases in credit spreads. This pattern - most pronounced for public-to-private buyouts - says that target firms often face a tightening of credit conditions after the buyout, an issue that we explore below.

Appendix Table D.3 shows how the industry mix of PE buyouts differs by deal type. For instance, public-to-private deals are relatively prevalent in Consumer Staples (e.g., food and household products) and Healthcare, while divisional deals are relatively prevalent in Information Technology and Utilities. A Pearson chi-squared test rejects the hypothesis that the industry distribution of buyouts is independent of deal type. The distributions of PE buyouts by industry, firm size, and firm age also differ greatly from the corresponding distributions of private sector employment (Davis et al., 2014). Given these patterns, our econometric investigations below compare buyout targets to control firms within cells defined by the full cross product of industry, firm size categories, firm age categories, multi-unit status, and buyout year.

\section{B. Matching Private Equity Buyouts to Census Micro Data}

The Longitudinal Business Database (LBD) is a longitudinal version of the Census Bureau's comprehensive Business Register (BR), which contains annual data on U.S. businesses with paid employees. The LBD covers the entire nonfarm private sector and, in recent years, has roughly 7 million establishment records and 5 million firm records per year. ${ }^{11}$ It draws on a wide range of administrative records and survey sources for data inputs. Firms are defined based on

\footnotetext{
${ }^{11}$ An establishment is a physical location where economic activity occurs. A firm is a legal entity that owns and operates one or more establishments.
} 
operational control, and all establishments majority owned by a parent firm are included in the parent's activity measures. Core data items include employment, payroll, four-digit Standard Industrial Classification (SIC) or six-digit North American Industrial Classification (NAICS) codes, employer identification numbers, business names, and location information.

To merge our buyout data to Census data on firms and establishments, we match business name and address information for the buyout targets to the name and address records in the BR. Table 2 summarizes our sample of PE buyouts matched to Census micro data. Panel A reports the number of establishments operated by our 6,000 matched target firms and their employment, with breakdowns by deal type. Panel B considers the 5,100 matched buyouts that closed from 1980 to 2011. Compared to the 1980-2003 sample in Davis et al. (2014), our new 1980-2011 analysis sample has 2.3 times as many matched targets, reflecting high deal flow after 2003. Private-toprivate deals account for about half of our 1980-2011 sample, as in our earlier work. The $22 \%$ share of secondary sales is nearly twice as large as in our earlier work, reflecting the large flow of these deals in recent years. The share of divisional buyouts is somewhat smaller in our new sample.

In our econometric analysis below, we limit attention to matched buyouts that closed from 1980 to 2011, so we can track their outcomes through 2013 in the LBD. We also drop target firms that we match to Census micro data using only taxpayer EINs (and not other firm IDs). As explained in Appendix A, we are not confident we can identify all establishments operated by the target firm in these EIN cases. Finally, we restrict our regression analysis to firms that we confidently track for two years post buyout. That leaves roughly 3,600 target firms in our regression analyses below, identified as "Two-year continuers" in Panel B of Table 2. Private-toprivate deals account for $29 \%$ of target employment as of the buyout year in this sample, public- 
to-private deals account for $36 \%$, divisional deals account for $11 \%$, secondary sales account for $19 \%$, and buyouts of unknown type for the rest.

Panel C compares matched buyouts in our new sample to those in Davis et al. (2014) for their 1980-2003 analysis period. Our new sample has about $20 \%$ fewer buyouts in the overlapping period, which reflects the more rigorous matching criteria that we now apply. Our new sample of two-year continuer targets (excluding EIN cases) has $10 \%$ fewer matched buyouts. The mix of buyout types in our new 1980-2003 sample is similar to the one in our earlier work.

\section{Empirical Results}

\section{A. Regression Specification, Weighting, and Identification}

We estimate firm-level regressions of the following form by least squares

$$
Y_{i, t+2}=\alpha+\sum_{c} D_{c i t} \theta_{c}+\lambda_{1} L E S T_{i t}+\lambda_{2} L F I R M_{i t}+\gamma P E_{i t}+\varepsilon_{i t},
$$

where $Y_{i, t+2}$ is the change in the outcome variable of interest from buyout year $t$ to two years later for firm $i .^{12}$ The $D_{\text {cit }}$ are cell-level dummy variables defined on the full cross product of buyout year $t$, the firm's three-digit NAICS, its size category, its age category, and an indicator for whether it owns multiple establishments. $L E S T_{i t}$ and $L F I R M_{i t}$ are controls for the firm's pre-buyout growth history. To construct $L E S T_{i t}$, we consider the set of establishments owned by firm $i$ in buyout year $t$ and compute their employment growth rate from $t-3$ to $t-1$. To construct $L F I R M_{i t}$, we consider the parent firm that owned these establishments in $t-3$ and compute its growth rate from $t-3$ to $t-1$. If ownership was split across multiple firms in $t-3$, we select the firm with the

\footnotetext{
${ }^{12}$ It is often impossible to track target firms over several years post buyout. However, Davis et al. (2014) track employment at target and control establishments for five years after buyout events. They find that establishment-level buyout effects over five years are about 90 percent larger than over two years, which suggests that results based on (1) understate the cumulative impact of buyout events on firm-level outcomes over several years.
} 
largest share of employment among these establishments. Often, but not always, these two control variables take on the same value. $P E_{i t}$ is a dummy variable equal to 1 for a target firm.

Buyout effects can vary with firm characteristics and economic conditions and by industry, deal type, and time period. However, there is surely more heterogeneity in treatment effects than we can estimate with precision. Faced with this heterogeneity, our goal is to obtain a consistent estimate for the activity-weighted mean treatment effect on treated units (i.e., buyout targets) under the under assumptions of conditional mean independence (CMI) and stable unit treatment value (SUTVA). To do so, we weight each target firm by its share of aggregate target activity, where "aggregate" refers to the sum over all buyouts in the regression sample. We weight each control unit in proportion to its employment share in its control cell, and rescale to equate the sum of weights on control units in a cell to the sum of weights on targets in the same cell. See Appendix B for additional discussion.

Our rich set of controls lends greater plausibility to the CMI assumption than in most previous work on PE buyouts. Even if CMI fails, our results provide useful evidence for formulating and evaluating theoretical models of PE behavior and its effects. The SUTVA assumption could fail if treatment effects on targets alter product demand and factor supply conditions facing controls, or if they exert competitive pressures that drive higher productivity at controls. Since targets typically account for modest activity levels relative to controls, these effects are likely to be quite small in our setting. Another possibility is that buyout targets implement superior technologies or business strategies that controls then emulate. The scope for such imitation effects also seems quite small within our two-year post-buyout time frame.

\section{B. The Average Economic Effects of Private Equity Buyouts}


Table 3 reports the estimated $\gamma$ coefficients and associated standard errors for regressions of the form (1). Coefficients are approximate percentage point changes from the buyout year $t$ to $t+2$. The "All Buyouts" column covers firms that underwent buyouts from 1980 to 2011 and matched control firms in the same cells. There are about 3,600 targets and 6.4 million total firmlevel observations in the regressions that consider employment growth and reallocation outcomes. The underlying number of establishments is much larger, because many target firms (and the corresponding control firms) have multiple facilities. We have fewer usable observations for labor productivity, as discussed below.

According to the "All Buyouts" column in Panel A, employment at target firms shrinks (on average) by a statistically insignificant 1.4 percentage points relative to control firms in the first two years after the buyout. Employment shrinks by 4.4 percentage points relative to controls when omitting post-buyout acquisitions and divestitures. These "bottom line" effects of PE buyouts on target firm employment are a bit larger than we found in Davis et al. (2014): - 0.9 percentage points overall, and -3.7 points for organic growth. Appendix Table D.4 provides more detail on how target-control employment growth outcomes differ by margin of adjustment. To summarize the largest differences, target firms are more aggressive than control firms in shutting establishments from $t$ to $t+2$ and in acquiring new establishments from $t$ to $t+2$.

While the net employment effects of PE buyouts attract much interest, buyouts have larger effects on the pace of job reallocation. Overall job reallocation for a firm is the sum of its gross job gains due to new, expanding, and acquired establishments and its gross job losses due to exiting, shrinking, and divested establishments. Dividing overall job reallocation by base employment yields the job reallocation rate. A firm's excess reallocation rate is the difference between its job reallocation rate and the absolute value of its net employment growth rate. If a firm 
changes employment in the same direction at all of its establishments, its excess reallocation is zero. To the extent that a firm expands employment at some units and contracts employment at others, it has positive excess reallocation. If a firm adds jobs at some establishments and cuts an equal number at other establishments, its excess reallocation equals its overall job reallocation. ${ }^{13}$

According to Panel B in Table 3, the job reallocation rate is higher by 7.1 percentage points (of base employment) at targets for organic employment changes over two years after the buyout and by 11.5 points when including acquisitions and divestitures, both highly significant. These results confirm that PE buyouts accelerate the pace of reallocation at target firms, more so when including acquisitions and divestitures. Turning to Panel C, excess reallocation is 5.0 percentage points higher at target firms for all changes, but insignificantly different for organic changes. The implication is that the faster pace of job reallocation induced by buyouts mainly involves greater reallocation of jobs across firms rather than within target firms. In other words, PE buyouts lead to net job losses at some target firms (relative to control firms) and net job gains at other target firms. The extra between-firm reallocation of jobs induced by PE buyouts equals 6.5 (11.5 - 5.0) percent of base employment over the first two years after the buyout.

Panel D in Table 3 provides evidence on how PE buyouts affect firm-level labor productivity, measured as the natural $\log$ of revenue per worker. ${ }^{14}$ Relative to Panels A-C, we lose observations for three reasons in Panel D. First, we cannot calculate productivity changes for firms that close all establishments by $t+2$. When we drop a target that dies in this sense, we also drop

\footnotetext{
${ }^{13}$ The excess reallocation concept is often used in the literature on gross job flows to analyze job reallocation within and across regions, industries and other categories. Examples include Dunne, Roberts, and Samuelson (1989) and Davis and Haltiwanger $(1992,1999)$. Here, we apply the same concept to the reallocation of jobs across establishments within the firm.

${ }^{14}$ RE-LBD labor productivity data are available in real terms using deflators at the NAICS2 and NAICS3 levels. These deflators have no effect on our estimates, which reflect productivity changes at targets relative to contemporaneous changes at controls within the same NAICS3.
} 
controls in the cell associated with that target. If we drop a cell with many controls, we lose many observations. Second, even for targets that survive, some control firms in the cell do not - leading to the loss of additional observations. Third, we drop observations for which firm-level productivity is more than $200 \log$ points from its mean in the same NAICS6-year cell in either the buyout year $t$ or in $t+2$. We drop these outliers to guard against large productivity deviations due to errors in the revenue data, errors in linking revenue and employment at the firm level, and errors in the assignment of firms to industries. See Haltiwanger et al. (2017) for a discussion of how these errors can arise in the RE-LBD and why revenue data are unavailable for many firms.

To address the potential selection bias introduced by missing productivity observations, we construct inverse propensity score weights as in Haltiwanger et al. (2017) and similarly to Davis et al. (2014). These weights ensure that the re-weighted RE-LBD is representative of the LBD universe with respect to the size, age, employment growth rate, industry sector, and multi-unit status of firms. We apply these weights and the activity weights described in Section II in our regression analysis of how PE buyouts affect productivity growth.

Turning to the results, labor productivity rises by 7.5 percentage points at targets relative to controls from buyout year $t$ to $t+2$. In undisclosed results, we find the largest post-buyout productivity gains at older and larger targets. Davis et al. (2014) estimate that PE buyouts raise total factor productivity by about 2.1 percentage points for target firms in the manufacturing sector. Here, we find a considerably larger effect of PE buyouts on labor productivity when looking across all industry sectors. To help understand this result, Panel C of Appendix Table D.4 decomposes this productivity gain into two pieces: one due to larger workforce reductions at targets, and the other due to greater revenue growth at targets. More than 80 percent of the estimated productivity gain reflects greater revenue growth at targets. We cannot decompose labor productivity gains into 
markup changes and physical productivity changes, given our data. However, Farcassi, Previtero, and Sheen (2018) show that the rapid post-buyout sales growth of retail and consumer products firms reflects the launch of new products and geographic expansion, not markup hikes.

\section{How the Effects Differ by Buyout Type}

Table 3 also reports estimated effects by type of buyout. According to Panel A, target employment shrinks by $12.6 \%$ (relative to controls) after private-to-public buyouts and by $11.5 \%$ after divisional buyouts. It rises by $12.8 \%$ after private-to-private buyouts and by $9.9 \%$ after secondary buyouts. Isolating organic changes, target employment shrinks by $10.0 \%$ after privateto-public buyouts and by $16.0 \%$ after divisional buyouts; it rises by $3.1 \%$ after private-to-private buyouts and by $6.1 \%$ after secondary buyouts. All of these estimates are statistically significant at the $1 \%$ or $5 \%$ level. Thus, we find strong evidence of buyout-induced employment effects that differ greatly by type of buyout. An F-test rejects the null hypothesis of no differences across buyout types in the estimated effects on target employment growth. ${ }^{15}$

Appendix Table D.5 provides more detail. For example, private-to-private and secondary buyouts create new job positions in new facilities at a faster clip than control firms - to the tune of $2.5 \%$ and $4.2 \%$ of base employment, respectively. In contrast, job creation at new facilities falls by $2.1 \%$ at targets relative to controls in public-to-private deals. Gross job destruction in the wake of divisional targets exceeds that of controls by $16 \%$ of base employment, mostly due to jobs lost in facility closures. A weaker version of the same pattern holds for public-to-private buyouts. Again, the key message is that employment effects of PE buyouts vary greatly by type of buyout.

15 To implement the tests (and those in Tables 5 and 6), we replace the $\gamma P E_{i t}$ in regression specification (1) with a set of four dummy variable terms, one for each buyout type. We then test for equality of the coefficients on these four dummy variables. 
Perhaps this heterogeneity should not surprise. As discussed above, public-to-private deals (and many divisional deals, which are typically carved out of public firms) involve targets with highly dispersed ownership. These firms may suffer from poor corporate governance before the buyout and face an intense need for cost cutting. Meanwhile, buyouts of privately held firms may more often be motivated by a desire to professionalize management or improve access to financing.

Turning to Panels B and $\mathrm{C}$ in Table 3, buyouts bring more reallocation, but the effect again differs greatly by deal type. In divisional deals, overall (excess) target job reallocation rises by $19.4 \%(10.0 \%)$ of base employment relative to controls, $17.1 \%$ (7.6\%) when netting out the role of acquisitions and divestments. In private-to-private deals, acquisitions and divestments entirely drive the post-buyout reallocation uptick at targets relative to controls. Buyouts bring higher job reallocation at targets in public-to-private deals but no statistically significant impact on excess job reallocation. This evidence implies - in line with our earlier discussion - that the extra job reallocation reflects a downsizing of some target firms (relative to controls) and an upsizing of others. Thus, targets show virtually no extra excess reallocation in public-to-private deals. By way of contrast, extra excess reallocation at target firms accounts for one-half to two-thirds of the extra buyout-induced job reallocation in the other deal types. The differences are significantly different at the $5 \%$ confidence level when examining the measures of organic reallocation.

Turning to productivity effects, we again find large differences by type of buyout, collectively significant at the $10 \%$ confidence level. Target firms in private-to-private deals experience a 14.7 percent productivity gain relative to controls. Targets in public-to-private deals enjoy similarly large gains, but the imprecise estimate precludes a sharp inference. Estimated productivity effects are smaller for other buyouts and statistically insignificant. 
Taken together, the results in Table 3 on differences by buyout type suggest that there is little basis for treating private-to-private, public-to-private, divisional, and secondary buyouts as homogeneous in their effects on jobs, reallocation, and productivity. But they are broadly consistent with the limited evidence in previous research on the real-side effects of PE buyouts. According to our evidence, private-to-private deals exhibit high post-buyout employment growth (largely but not entirely via acquisitions) and large productivity gains. Meanwhile, public-toprivate deals exhibit large job losses, often through facility closures, and large (imprecisely estimated) productivity gains. Divisional buyouts similarly involve large employment losses and massive reallocation effects. Finally, secondary deals exhibit high target employment growth, largely organic, high reallocation and few discernible effects otherwise. ${ }^{16}$

\section{How Buyout Effects Vary with Market Conditions at Close}

We now investigate how the economic effects of PE buyouts vary with market conditions when the deal closes. To do so, we estimate richer regression specifications of the form, $Y_{i, t+2}=\alpha+\sum_{c} D_{c i t} \theta_{c}+\lambda_{1} L E S T_{i t}+\lambda_{2} L F I R M_{i t}+\gamma P E_{i t}+\beta P E_{i t} *$ MktCondition $_{t}+\varepsilon_{i t}$,

where the new term, $\beta P E_{i t} * M k t$ Condition $_{t}$, captures the interaction between buyout status and market conditions. When using intra-year variation in market conditions, we also include the

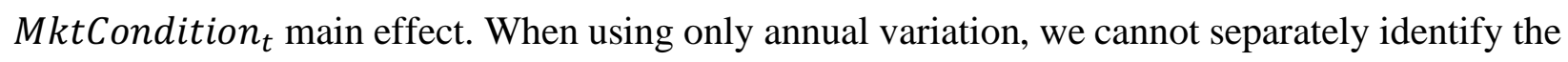
main effect, since our cell-level controls encompass annual time effects.

We consider two measures of market conditions at the buyout close: the log change in real GDP over the four quarters leading up to (and including) the closing quarter, and the spread

\footnotetext{
${ }^{16}$ Secondary deals are somewhat of a grab bag, with PE groups on both sides of the transaction. That makes it hard to interpret the effects of secondary buyouts. Hence, and in the interest of brevity, we do not report breakouts for secondary deals in the rest of the paper.
} 
between high-yield U.S. corporate bonds and the one-month U.S. LIBOR in the closing month. ${ }^{17}$ Similar spread measures are widely used in the finance literature to characterize debt market conditions. Notably for our analysis, Axelson et al. (2013) show that this spread varies negatively in the extent the buyout transaction is levered and with the EBITDA-multiple paid, and positively with the ultimate financial return on the buyout to PE investors.

The macroeconomics literature offers multiple interpretations for the relationship of spreads to real activity. Viewed through the lens of the $q$-theory of investment, low bond prices (a high spread) reflect low expected returns to capital (Philippon, 2009). Gilchrist and Zakrajšek (2012) advance a different view. They highlight a major role for movements in "the compensation demanded by investors - above and beyond expected losses - for bearing exposure to corporate credit risk." As they also show, movements in this excess bond premium mirror movements in the equity valuations of financial intermediaries and in their credit default swap premiums. This evidence is broadly in line with our interpretation: a high spread reflects tight credit conditions.

Turning to the results in Table 4, we find no evidence that the post-buyout performance of target firms (again, relative to controls) varies with GDP growth in the four quarters leading up to the close. The $\beta$ coefficients on the interaction term are imprecisely estimated and statistically insignificant for each dependent variable. In contrast, higher credit spreads at close involve large, statistically significant effects on excess reallocation and productivity growth. ${ }^{18}$ Raising the credit

${ }^{17}$ GDP data are from the U.S. Bureau of the Economic Analysis, and the interest rate measures are from Datastream. For the bond rate, we use the yield to maturity on the Bank of America Merrill Lynch U.S. High Yield Index.

${ }^{18}$ From 1980 Q1 to 2013 Q4, the correlation between (a) the credit spread at quarter's end and (b) real GDP growth from four quarters previous to the quarter in question is a modest -0.288 . In unreported results, we tried two other measures of external financial conditions: the credit spread measure of Gilchrist and Zakrajšek (2012), and equity market valuations, measured as the ratio of end-of month equity prices to the trailing twelve-month earnings S\&P 500 firms. These alternative measures yielded broadly similar, but somewhat noisier, results. 
spread by one standard deviation corresponds to a post-buyout productivity gain of 20.3 percent for targets relative to controls and an increase in excess reallocation of 4.6 percent of base employment. These large effects come on top of the baseline effects reported in Table 3.

The positive association between excess reallocation rates and productivity gains as credit conditions vary suggests that PE buyouts achieve productivity improvements by shifting inputs toward better uses within target firms. In a similar spirit, Davis et al. (2014) find that buyouts lead to TFP gains at target firms in the manufacturing sector, mainly due to the reallocation of activity from less productive plants to more productive ones. Here, we find that high credit spreads at the time of the buyout lead to greater productivity gains and greater reallocation activity in target firms in the two years after the buyout. Both sets of results link buyout-induced productivity gains to an accelerated, purposefully directed reallocation of activity within target firms.

Our credit spread results in Table 4 also suggest that PE groups have multiple tools for earning returns on their investments in portfolio firms. When credit is cheap and readily available, it may be more attractive to rely on financial engineering tools to generate returns, e.g., by issuing new debt to fund additional dividend payments to equity holders. When credit is costly and tight, financial engineering is less feasible and PE groups may generate returns through operational improvements that raise productivity in portfolio firms.

\section{E. How Buyout Effects Vary with the Evolution of Market Conditions After the Close}

We now consider how buyout effects vary with the evolution of market conditions after the close of the deal. We measure post-buyout changes in market conditions from March (or the 
first quarter) of the buyout year $t$ to March (first quarter) of year $t+2 .{ }^{19}$ Table 5 focuses on the postbuyout change in credit conditions, and Table 6 focuses on post-buyout growth in real GDP.

Consider the results for all buyouts. Faster GDP growth in the two-year interval after buyouts brings greater post-buyout employment growth at targets relative to controls and greater excess reallocation. These effects are statistically significant and large: A unit standard deviation rise in the post-buyout GDP growth rate raises employment growth at targets relative to controls by 3.2 percent of base employment, and it raises target excess reallocation by 3.0 percent of base employment. A rise in credit spreads after buyouts brings slower post-buyout employment growth at targets relative to controls and slower excess reallocation. These effects are statistically significant and similar in magnitude to the ones associated with a unit standard deviation change in the GDP growth rate.

Figure 2 illustrates how post-buyout employment growth and excess reallocation at target firms (relative to controls) vary with the evolution of GDP growth and credit spreads. In the top panel, the baseline employment growth effect depicted in the center bar is of modest size, in line with our results in Table 3. However, the relative post-buyout employment performance of targets is highly sensitive to the evolution of market conditions. For example, a post-buyout decline in GDP growth by two standard deviations lowers the relative employment growth of targets by $7 \%$. Changing credit spreads lead to a similar pattern in the lower panel. Excess reallocation rates at target firms are also sensitive to the post-buyout evolution of market conditions.

Tables 5 and 6 also report results by deal type. Recall that average buyout effects vary greatly by deal type (Table 3), and the mix of buyouts by deal type varies over the economic and

\footnotetext{
${ }^{19}$ Similar results obtain when using the change from the buyout closing date in year $t$ to March of year $t+2$.
} 
credit cycles (Figure 1 and Table 1). In line with remarks in Section I.B, Tables 5 and 6 provide evidence that the productivity effects are more sensitive to post-buyout macroeconomic and credit conditions for public-to-private than private-to-private deals, with divisional deals in the middle. In particular, when GDP grows faster or credit spreads narrow, the productivity growth of target firms is even higher (relative to controls) for the targets of public-to-private and divisional buyouts. A similar pattern holds for excess reallocation, except divisional buyouts show a greater sensitivity than public-to-private deals to post-buyout macroeconomic and credit conditions.

As articulated above, one explanation is that high leverage in public-to-private deals prevents management and investors from implementing pre-buyout operating plans when market conditions deteriorate or credit tights, with negative implications for productivity and reallocation. A similar dynamic may hold for divisional buyouts, which are likely to resemble public-to-private deals along important dimensions. Interestingly, the pattern goes the other way in private-toprivate deals: deteriorating economic conditions or tighter credit conditions lead to greater productivity gains at targets relative to controls.

We do not find strong differences across buyout types in the responsiveness of target employment levels to post-buyout economic and credit conditions. For the most part, these interaction effects on target employment growth are statistically insignificant.

\section{F. Two Robustness Checks}

We now address two potential concerns about the forgoing analysis of market conditions. First, perhaps the results reflect our particular metrics for market conditions. Second, the results might be largely driven by the many buyouts undertaken in the run-up to the global financial crisis.

Table 7 addresses the first concern. Rather than looking at how buyout effects vary with a continuous measure of market conditions, we now take a simpler approach. Specifically, we 
interact the buyout indicator with a dummy for whether (a) the deal was executed during a recession or (b) the U.S. economy entered a recession in the two years after deal execution. Recession years are those for which at least half the months were part of NBER-designated recessions (i.e., 1981-82, 1990, 2001, and 2008-09). Table 7 reports these results for specifications and samples that parallel the ones in Table 4 and the "All Buyouts" columns in Tables 5 and 6.

The relative employment responsiveness of target firms to recessions is, if anything, stronger than when using continuous metrics. Both overall and organic employment growth at targets worsens (relative to controls) when the economy enters a recession after the buyout. Relative employment growth at targets is stronger for deals executed during a recession. Also, akin to results in Tables 5 and 6 , deteriorating economic conditions post-buyout involve less reallocation at targets. Coefficients on the recession interaction variable in these cases are roughly equal to a three standard deviation shift in the continuous interaction variables in Tables 5 and 6. The productivity regressions, however, show smaller coefficients for the interaction variables and less statistical significance than obtained with continuous measures of economic conditions. Nevertheless, Table 7 indicates that our results continue to hold when using the recession indicator of market conditions rather than the continuous measures considered above.

Turning to the second concern, Figure 1 shows a huge surge in buyout activity in the quarters leading up to the GFC. Recall that the economy appeared strong in 2007 but then tumbled into a deep recession in 2008-09. To assess whether the runup in buyouts before the GFC drives our results, we re-estimated our models after dropping buyouts done in 2007. Table 8 repeats models considered in Tables 4, 5 and 6, but now omitting all targets and controls for buyouts in 2007. (Results are similar when also dropping buyouts in 2006.) By and large, the results are similar to before: Deals done amidst higher credit spreads show much greater productivity growth 
at targets. And, widening credit spreads and greater GDP growth after buyouts are associated with more reallocation at targets. The coefficients remain roughly the same size, but the responsiveness of target employment growth to economic conditions is weaker than before. In short, our results are not particularly driven by deals done in the run-up to the GFC.

\section{G. Market Conditions, or Deal Mix Changes over Time?}

Recall that public-to-private buyout volume is more pro-cyclical than that of other buyout types, especially private-to-private deals (Table 1). So, perhaps the greater job losses at target firms in public-to-private buyouts (Table 3) reflect a greater pro-cyclicality in their deal volume.

The sensitivity of our estimated buyout effects to market conditions could also reflect changes in the mix of PE sponsor characteristics over time. Gompers and Lerner (1999) and Kaplan and Schoar (2005), among others, show that the number of first-time funds is especially procyclical. If the targets of young buyout groups have more adverse employment outcomes and are concentrated around market peaks, it could drive a cyclical pattern in our estimated effects of PE buyouts. More generally, a changing mix of active PE funds could drive time variation in the estimated PE effects. If true, that would be an interesting finding, but it would put our earlier results on the sensitivity of buyout effects to market conditions in a somewhat different light.

To explore these matters, we first undertook another large data collection effort to identify and characterize the PE sponsors of our nearly ten thousand buyouts. For $89 \%$ of the buyouts, we found information about the PE group in Preqin, Refinitiv, and other public sources. We assigned each PE group an identifier that follows the organization through spin-outs and name changes, as explained in Appendix C. We also gathered information about the organization type of the PE group, the number and dollar volume of its previous funds raised, and the group's historical track record (when available). We then merged these new data with our other data. 
To analyze whether changes over time in the mix of buyout types and PE sponsor characteristics explain our results on how buyout effects vary with market conditions, we adopt a simple approach that lends itself to a useful decomposition, as we will explain. Specifically, for each buyout we create a "cell-adjusted" performance measure equal to the change from buyout year $t$ to $t+2$ for the target minus the contemporaneous mean change for controls in the same cell (defined as before). We now dispense with controls for pre-buyout growth. We then sort observations by high and low values of a market conditions variable. Then we regress the celladjusted outcomes for buyout targets on a constant and the market conditions indicator, weighting buyout observations in the same way as before.

Panel A of Table 9 confirms that this simpler approach yields results very similar to the earlier ones on how target outcomes vary with market conditions. Specifically, relative target employment growth and reallocation rates increase when post-buyout GDP growth is high, and relative target productivity gains are greater for deals that close when credit spreads are high.

Next, we implement a Blinder-Oaxaca decomposition of the difference in relative target performance between high and low values of the market conditions variable. This type of decomposition has a long history in labor economics (Jann, 2008), but it can be readily applied to decompose the estimated difference between any two groups. In our application, the two groups are buyouts associated with high and low values, respectively, of a market conditions variable. For each subsample (i.e., the high-value and low-value observations), we regress the cell-adjusted buyout performance measure on indicator variables for buyout types and four measures of PE sponsor characteristics: the number of funds raised by the sponsor in the five years prior to its buyout of the target firm; the dollar amount it raised in the five years prior to the deal, divided by total U.S. PE fundraising in the same period; a dummy for whether the sponsor was independent, 
as opposed to a bank or corporate affiliate; and the number of buyouts undertaken by the sponsor in a five-year period around the deal in question. These measures quantify PE sponsor attributes related to the scale of its buyout activity, its fundraising success (a proxy for past performance), and its organization type.

The subsample regressions provide the ingredients of a Blinder-Oaxaca decomposition for the high-low difference in Panel A. We can express the decomposition as

$$
\left(\bar{X}_{H}-\bar{X}_{L}\right)^{\prime} \hat{\beta}_{H}+\bar{X}_{H}^{\prime}\left(\hat{\beta}_{H}-\hat{\beta}_{L}\right)+\left(\bar{X}_{H}-\bar{X}_{L}\right)^{\prime}\left(\hat{\beta}_{L}-\hat{\beta}_{H}\right)
$$

where $\bar{X}_{H}$ and $\bar{X}_{L}$ are vectors whose elements are the mean values of the explanatory variables in the "high" and "low" regression samples, respectively; and the $\hat{\beta}_{H}$ and $\hat{\beta}_{L}$ are the corresponding least squares regression coefficient vectors. The first term of (3) quantifies the contribution of changes in the mix of buyout types and PE sponsor characteristics to the high-low difference, the second term quantifies the contribution of market conditions, and the third term captures the interaction of between-group differences in the $\bar{X}$ and $\bar{\beta}$ vectors.

Panel B reports the decomposition results. The values in row (2) are statistically significant and roughly the same size as the corresponding high-low differences in Panel A. That is, the between-sample differences in the estimated coefficients largely account for the high-low differences in panel A. Moreover, for the employment growth rate and excess reallocation rate, the other two terms in the decomposition are small and statistically insignificant. Thus, for employment growth and excess reallocation, Table 9 confirms that buyout effects vary strongly with market conditions, and there is little role for temporal variation in the mix of buyout types and PE sponsor characteristics.

The message for buyout effects on productivity is murkier in two respects: the individual terms on the right side of (3) are imprecisely estimated because of the small sample, and the first 
and third terms are large and nearly offsetting. Our earlier claim that buyouts executed amidst tight credit conditions yield stronger productivity gains at targets still holds. However, we cannot say with any confidence whether, and to what extent, this result reflects time variation in PE sponsor characteristics or types of buyouts.

\section{H. Do Buyout Effects Differ across Private Equity Groups?}

Thus far, we have provided evidence that the real-side effects of PE buyouts differ with market conditions post buyout, with market conditions at close, by type of buyout, and with interactions between market conditions and buyout type. Another potential driver of heterogeneity in buyout effects are systematic differences among the PE sponsors themselves. ${ }^{20}$

As noted above, PE groups are characterized by management stability and distinct investment styles. In addition, persistence in financial performance has often been seen as a distinguishing feature of private equity groups, in contrast to hedge funds and mutual funds. (See Carhart (1997) and Brown, Goetzmann, and Ibbotson (1999) on hedge funds and mutual funds.) Studies that document persistence in the returns of PE groups include Kaplan and Schoar (2005), Ewens and Rhodes-Kropf (2015), Braun, Jenkinson and Stoff (2017), and Harris et al. (2020). We now investigate whether there are also persistent differences across PE groups in the employment effects of their buyouts. While it would be interesting to analyze persistence in productivity effects as well, we have too few buyouts with productivity data for an informative analysis.

To explore the impact of PE groups, Table 10 presents a series of regressions inspired by Kaplan and Schoar (2005) and Harris et al. (2020, and its 2014 predecessor). These authors examined persistence of financial performance at the fund level. Because it is hard for us to

20 Table 9 speaks to whether PE sponsor characteristics explain differences in buyout effects between periods with high and low market conditions. This section and the next investigate whether PE sponsors and their characteristics influence buyout effects on average. 
associate buyouts with particular funds, we instead aggregate all transactions associated with a given PE group in each of seven non-overlapping periods (1980-84, 1985-89, .., 2005-09, and 2010-11). As in the preceding section, we use the cell-adjusted employment growth rate over the two years after each buyout. For each period and PE group, we then compute the mean value of the cell-adjusted growth rates. We regress this period-by-PE group mean on its own lagged value (for the previous five-year period), dropping PE groups with buyouts in only one five-year period. We include time period dummies as well.

The results in columns (1) and (6) of Table 10 point to persistence over time at the PE group level in the employment effects of their buyouts. Persistence is much stronger, and statistically significant, for organic employment growth. The coefficient of 0.12 on lagged organic growth in regressions (6) through (8) compares to that of 0.17 in the public-market-equivalent buyout analysis of Kaplan-Schoar $\left(2005 ; 8^{\text {th }}\right.$ regression in Table VII). This pattern supports the view that PE groups differ in their approach to operational improvements at target firms, leading to systematic differences in buyout effects on organic employment growth, while target-specific considerations influence decisions to acquire and divest. These results are robust to adding controls for the PE sponsor's volume of transactions in the five-year period and the change in its volume from the previous five-year period, as seen in columns (2), (3), (7) and (8).

The remaining columns contain two additional results. First, when we add an interaction between the date (expressed here as years since January 1960) and lagged employment growth (again at the group level), no evidence emerges of falling persistence in the group-specific growth effects. In contrast, the work of Harris et al. (2020) suggests that persistence in the financial performance of buyout funds dropped sharply after 2000. While PE groups may no longer show persistent differences in their ability to monetize their distinct approaches, our results say they 
continue to show persistent differences in how they affect target firms. Second, when we add firm fixed effects in columns (6) and (10), we obtain results similar to those in Table 9 of Harris et al. (2014): the coefficient on lagged performance turns sharply negative, which says there is regression to the (group-specific) mean in the employment growth rates of buyout targets.

\section{How Does Scaling at the Group Level Affect Employment in Portfolio Firms?}

Our final analysis investigates how scaling in buyout activity at the group level affects employment outcomes at targets. Previous research finds a detrimental impact of increasing fund size on fund manager returns - see, for example, Fung et al. (2008) for hedge funds (2008) and Chen et al. (2004) for mutual funds. Similarly, the work of Lopez-de-Silanes, Phalippou, and Gottschalg (2015) and Rossi (2019) suggests a negative relationship between the upscaling in buyout activity and the financial performance of PE groups.

Motivated by these earlier works, we investigate how the scaling of buyout activity by PE groups relates to the employment growth of their portfolio companies. To do so, we expand specification (1) to include variables that directly measure aspects of scaling or proxy for it, while also adding controls for buyout type. We consider four measures of scaling: funds raised by the PE group from $t-4$ to $t$ for buyouts in $t$, divided by total buyout funds raised in the same period; financial performance of the group's last two buyout funds raised in the window from $t-12$ to $t-5$, calculated as returns as a multiple of invested capital (MoIC) minus the benchmark MoIC raised in the same period; the number of buyouts executed by the PE group in the five-year period (1980-84, 1985-89, and so forth) that contains the buyout year; and the change in the number of buyouts from the previous to the current five-year period. Appendix $\mathrm{C}$ explains how we constructed these scaling measures. 
As shown in Table 11, upscaling in buyout activity at the group level involves lower postbuyout employment growth at target firms (again, relative to controls). The estimated upscaling effects are statistically significant at the 10 percent level for all scaling measures except for the change in the number of buyout deals. The estimated magnitudes differ a good deal. For example, a unit standard deviation increase in Adjusted Financial Performance involves a 4.4 percentage point decrease in the relative growth of organic employment at target firms, whereas a unit standard deviation increase in Funds Raised in Prior Five Years (Number of Buyouts in Current Five-Year Period) involves a decrease of only $0.7(0.1)$ percentage points. $^{21}$

In summary, upscaling in PE buyout groups is associated with a more negative employment impact on target firms, even after controlling for buyout type, the target's pre-buyout growth history and cell-level fixed effects. Of course, the scaling of PE groups is not exogenous (Rossi, 2019). In particular, past performance has a profound influence on the ability to raise new funds (Chung et al., 2012). Seen in this light, the results in Table 11 suggests that past success encourages a PE group to scale up its buyout activity, diluting the attention that key group personnel devote to individual portfolio companies. In turn, this dilution of attention leads to weaker employment growth among portfolio companies.

\section{Concluding Remarks}

In his presidential address to the American Finance Association, Zingales (2015) makes the case that we "cannot argue deductively that all finance is good [or bad]. To separate the wheat from the chaff, we need to identify the rent-seeking components of finance, i.e., those activities that while profitable from an individual point of view are not so from a societal point of view."

${ }^{21}$ The larger implied effect for the Adjusted Financial Performance measure arises, at least in part, because its values are more highly dispersed across PE groups, as reflected in its relatively large coefficient of variation (ratio of standard deviation to mean). 
Our study takes up that challenge for private equity buyouts, a major financial enterprise that critics see as dominated by rent-seeking activities with little in the way of societal benefits. We find that the real-side effects of buyouts on target firms and their workers vary greatly with market conditions, by type of buyout, across the private equity groups that sponsor buyouts, and with the sponsor's scale of buyout activity. To continue the metaphor, separating wheat from chaff in private equity requires a fine-grained analysis.

This conclusion cast doubts on the efficacy of "one-size-fits-all” policy prescriptions for private equity. Buyouts are associated with large productivity gains in many but not all circumstances. They are associated with large job losses in some circumstances and large job gains in others. This mixture of consequences presents serious challenges for policy design, particularly in an era of slow productivity growth (which ultimately drives living standards) and concerns about economic inequality.

There is a keen need to better understand the link between PE buyouts and productivity growth. Our evidence that buyouts executed amidst easy credit conditions bring smaller productivity gains suggests that PE groups exercise some latitude in how they create value for their investors. When credit is cheap and easy, PE groups may select buyouts - or structure them - to deliver private returns via financial engineering rather than operating improvements. Many PE groups were founded and seeded by investment bankers that historically relied on financial engineering to create private value, employing strategies such as repeatedly re-leveraging firms and dividending out excess cash (Gompers, Kaplan, and Mukharlyamov, 2016). In this light, it is unsurprising if PE groups de-emphasize operating improvements when leverage and dividends deliver high private returns. That said, our study provides evidence that buyout can, and often do, 
drive large productivity improvements in target firms. Policies that harness the power of PE buyouts to drive productivity gains can bring high social returns along with high private returns.

Our results reinforce some concerns about public-to-private deals, which account for $10 \%$ of PE buyouts from 1980 to 2013 and 31\% of employment in target firms. In particular, public-toprivate deals proliferate in advance of credit market tightening, and their targets exhibit poor productivity performance during aggregate downturns and when credit spreads widen.

Our study also points to several important outstanding questions: Do public-to-private and divisional buyouts cause avoidable employment losses? Or were targets in dire need of restructuring and retrenchment to prevent worse outcomes at a later date? More broadly, are job losses after certain types of buyouts essential to achieve post-buyout productivity gains and, if so, is the tradeoff an acceptable one? Does the pro-cyclical employment impact of buyouts reflect socially undesirable risk-taking by private equity or a preferred point on the risk-return frontier with social benefits in the form of high expected productivity gains? Resolving these questions is likely to require guidance from theory and novel identification techniques, but we hope our study helps pave the way to future research on these issues. Future studies that encompass more buyouts will be able to more fully examine the heterogeneous economic effects of buyouts.

Another important avenue for exploring these questions is to link private equity transactions to the Longitudinal Employee-Household Dynamics (LEHD) database. LEHD records on individuals will allow economists to study buyout effects on the compensation, unemployment spells, and employment trajectories of workers and to investigate spillover effects on local economies. We hope to pursue this research agenda in the years to come. 


\section{References}

Autor, David, David Dorn, Lawrence F Katz, Christina Patterson, and John Van Reenen, 2020. "The fall of the labor share and the rise of superstar firms," Quarterly Journal of Economics. 135, 645-709.

Axelson, Ulf, Tim Jenkinson, Per Strömberg, and Michael Weisbach. 2013. "Borrow cheap, buy high? The determinants of leverage and pricing in buyouts." Journal of Finance, 68, 22232267.

Axelson, Ulf, Per Strömberg, and Michael S. Weisbach, 2009, "Why are buyouts levered? The financial structure of private equity funds." Journal of Finance, 64, 1549-1582.

Benmelech, Efraim, Nittai K. Bergman, and Ricardo J. Enriquez, 2012. "Negotiating with labor under financial distress." Review of Corporate Finance Studies, 1, $28-67$.

Bernanke, Ben, and Mark Gertler, 1987. "Banking and macroeconomic equilibrium," in New Approaches to Monetary Economics: Proceedings of the Second International Symposium in Economic Theory and Econometrics, edited by William A. Barnett and Kenneth J. Singleton. Cambridge: Cambridge University Press, 89-112.

Bernanke, Ben, Mark Gertler and Simon Gilchrist, 1999. "The financial accelerator in a quantitative business cycle framework," in Handbook of Macroeconomics, edited by John B. Taylor and Michael Woodford. New York, North-Holland, Volume I, 1341-1393.

Bernstein, Shai, Josh Lerner, and Filippo Mezzanotti, 2019. "Private equity and financial fragility during the crisis." Review of Financial Studies, 32, 1309-1373.

Bernstein, Shai, and Albert Sheen, 2016. "The operational consequences of private equity buyouts: Evidence from the restaurant industry." Review of Financial Studies, 29, 2387-2418.

Bertrand, Marianne, and Antoinette Schoar, 2003. "Managing with style: the effect of managers on firm policies." Quarterly Journal of Economics, 118, 1169-1208.

Bloom, Nicholas, Raffaella Sadun, and John Van Reenen, 2015. "Do private equity owned firms have better management practices?" American Economic Review Papers and Proceedings, 105, 442-446.

Bloom, Nicholas, and John Van Reenen, "Measuring and explaining management practices across firms and countries." Quarterly Journal of Economics, 122, 1351-1408.

Boucly, Quentin, David Sraer, and David Thesmar, 2011. "Growth LBOs.” Journal of Financial Economics, 102, 432-453.

Brau, James C. and Stanley E. Fawcett, 2006. "Initial public offerings: An analysis of theory and practice." Journal of Finance, 61, 399-436. 
Braun, Reiner, Tim Jenkinson, and Christoph Schemmerl, 2020. "Adverse selection and the performance of private equity co-investments," Journal of Financial Economics, 136, 4462.

Brown, Stephen, William Goetzmann, and Roger G. Ibbotson, 1999. "Offshore hedge funds: Survival and performance, 1989-95,” Journal of Business, 72, 91-117.

Campello, Murillo, John R. Graham, and Campbell R. Harvey, 2010. "The Real Effects of Financial Constraints: Evidence from a Financial Crisis." Journal of Financial Economics, 97, 470-487.

Carhart, Mark M., 2007. “On persistence in mutual fund performance.” Journal of Finance, 52, 57-82.

Chemmanur, Thomas J., and Paolo Fulghieri, 1999. "A theory of the going-public decision." Review of Financial Studies, 12, 249-279.

Chen, Joseph, Harrison Hong, Ming Huang and Jeffrey D. Kubik, 2004. "Does fund size erode mutual fund performance? The role of liquidity and organization." American Economic Review, 94, 1276-1302.

Chung, Ji-Woong, Berk A. Sensoy, Léa Stern, and Michael S. Weisbach, 2012. "Pay for performance from future fund flows: The case of private equity." Review of Financial Studies, 25, 3259-3304.

Cohn, Jonathan B., Lillian F. Mills, and Erin M. Towery, 2014. "The evolution of capital structure and operating performance after leveraged buyouts: Evidence from U.S. corporate tax returns." Journal of Financial Economics, 111, 469-494.

Cohn, Jonathan B., Nicole Nestoriak, and Malcolm Wardlaw, 2019. "Private equity buyouts and workplace safety." Unpublished working paper, https://ssrn.com/abstract=2728704.

Davis, Steven J., and John Haltiwanger, 1992. "Gross job creation, gross job destruction, and employment reallocation." Quarterly Journal of Economics, 107, 819-863.

Davis, Steven J., and John Haltiwanger, 1999. "Gross job flows," in Handbook of Labor Economics, edited by David Card and Orley Ashenfelter. New York: North-Holland, Volume 3B, 2711-2805.

Davis, Steven J., John Haltiwanger, Kyle Handley, Ron Jarmin, Josh Lerner, and Javier Miranda, 2014. "Private equity, jobs, and productivity." American Economic Review, 104, 39563990.

Dunne, Timothy, Mark J. Roberts, and Larry Samuelson, 1989. "The growth and failure of U. S. manufacturing plants.” Quarterly Journal of Economics, 104, 671-698. 
Farcassi, Cesar, Alessandro Previtero, and Albert Sheen, 2018. "Barbarians at the store? Private equity, products, and consumers.” Kelley School of Business, Indiana University, Research Paper no. 17-12, https://papers.ssrn.com/sol3/papers.cfm?abstract_id=2911387.

Fung, William, David A. Hsieh, Narayan Y. Naik, and Tarun Ramadorai, 2008. "Hedge funds: Performance, risk, and capital formation.” Journal of Finance, 63, 1777-1803.

Gilchrist, Simon, and Egon Zakrajšek, 2012. "Credit spreads and business cycle fluctuations." American Economic Review, 102, 1692-1720.

Gompers, Paul, Steven N. Kaplan and Vladimir Mukharlyamov, 2016. "What do private equity firms say they do?" Journal of Financial Economics, 121, 449-476.

Haltiwanger, John, Ron S. Jarmin, Robert Kulick, and Javier Miranda, 2017. "High growth young firms: Contribution to job growth, output, and productivity growth" in Measuring Entrepreneurial Businesses: Current Knowledge and Challenges, edited by John Haltiwanger, Erik Hurst, Javier Miranda, and Antoinette Schoar. University of Chicago Press, 11-62.

Harris, Robert S., Tim Jenkinson, and Steven N. Kaplan, 2016. "How do private equity investments perform compared to public equity?" Journal of Investment Management, 14 (3), 1-24.

Harris, Robert S., Tim Jenkinson, Steven N. Kaplan, and Ruediger Stucke, 2014. "Has persistence persisted in private equity? Evidence from buyout and venture capital funds." Unpublished working paper, https://www.calpers.ca.gov/docs/boardagendas/201511/invest/Workshop02-02d.pdf.

Harris, Robert S., Tim Jenkinson, Steven N. Kaplan, and Ruediger Stucke, 2020. "Has persistence persisted in private equity? Evidence from buyout and venture capital funds." University of Chicago, Becker Friedman Institute for Economics Working Paper No. 2020-167, https://ssrn.com/abstract=3736098.

Hellman, Thomas and Manju Puri, 2002. "Venture capital and the professionalization of start-up firms: Empirical evidence," Journal of Finance, 57 no. 1, 169-197.

Hotchkiss, Edith S., Per Strömberg, and David C. Smith, 2014. "Private equity and the resolution of financial distress." European Corporate Governance Institute, Finance working paper no. 331, https://papers.ssrn.com/sol3/papers.cfm?abstract_id=1787446.

Ivashina, Victoria, and Anna Kovner, 2011. "The private equity advantage: Leveraged buyout firms and relationship banking." Review of Financial Studies, 24, 2462-2498.

Jann, Ben, 2008. "The Blinder-Oaxaca decomposition for linear regression models," The Stata Journal, 4, 453-479. 
Jensen, Michael C., 1989. "The eclipse of the public corporation.” Harvard Business Review, 67 (5), 61-74.

Jensen, Michael C., Willy Burkhardt, and Brian Barry, 1989. "Wisconsin Central Ltd. Railroad and Berkshire Partners (A) and (B): Leveraged buyouts and financial distress," Harvard Business School case nos. 190062 and 190070.

Jensen, Michael C., and William H. Meckling, 1976. "Theory of the firm: Managerial behavior, agency costs and ownership structure." Journal of Financial Economics, 3, 305-360.

Kaplan, Steven N., 1989. "The effects of management buyouts on operating performance and value." Journal of Financial Economics, 24, 217-254.

Kaplan, Steven N., and Antoinette Schoar, 2005. "Private equity performance: Returns, persistence, and capital flows." Journal of Finance, 60, 1791-1823.

Kaplan, Steven N., and Jeremy Stein, 1993. "The evolution of buyout pricing and financial structure in the 1980s." Quarterly Journal of Economics, 108, 313-357.

Kindleberger, Charles P., 1978. Manias, Panics, and Crashes: A History of Financial Crises. New York: Basic Books.

Lerner, Josh, and Diana Noble, 2021. "When to go and how to go? Founder and leader transitions in private equity firms." Journal of Alternative Investments, forthcoming.

Lerner, Josh, Abhijit Tagade, and Terrence Shu, 2018. "Clayton, Dubilier \& Rice at 40." Harvard Business School Case no. 9-819-055.

Lichtenberg, Frank R. and Donald Siegel, 1990. "The effects of leveraged buyouts on productivity and related aspects of firm behavior.” Journal of Financial Economics, 27, 165-94.

Lopez-de-Silanes, Florencio, Ludovic Phalippou and Oliver Gottschalg, 2015. "Giants at the gate: Investment returns and diseconomies of scale in private equity." Journal of Financial and Quantitative Analysis, 50, 377-411.

Maksimovic, Vojislav, and Pegaret Pichler, 2001. "Technological innovation and initial public offerings." Review of Financial Studies, 14, 459-494.

Pagano, Marco, Fabio Panetta, and Luigi Zingales, 1998. "Why do companies go public? An empirical analysis." Journal of Finance, 53, 27-64.

Philippon, Thomas, 2009. “The bond market's q." Quarterly Journal of Economics, 124, 1011-56.

Rajan, Raghuram G., 1994. "Why bank credit policies fluctuate: A theory and some evidence." Quarterly Journal of Economics, 109, 399-441. 
Reinhart, Carmen M. and Kenneth S. Rogoff, 2009. This Time Is Different: Eight Centuries of Financial Folly. Princeton: Princeton University Press.

Rossi, Andrea, 2019. "Decreasing returns or reversion to the mean? The case of private equity fund growth," Unpublished working paper, https://ssrn.com/abstract=3511348.

Schularick, Moritz and Alan M. Taylor, 2012. "Credit booms gone bust: Monetary policy, leverage cycles, and financial crises, 1870-2008." American Economic Review, 102, 1029-1061.

Shleifer, Andrei, and Lawrence H Summers, 1988. "Breach of trust in hostile takeovers," in Corporate Takeovers: Causes and Consequences, edited by Alan J. Auerbach. Chicago: University of Chicago Press, pp. 33-56.

Strömberg, Per, 2008, "The new demography of private equity," in Globalization of Alternative Investment Working Papers: The Global Economic Impact of Private Equity Report, edited by Anuradha Gurung and Josh Lerner. Geneva, World Economic Forum, vol. 1, 3-26.

Syverson, Chad, 2011. "What determines productivity?" Journal of Economic Literature, 49, 32665.

Wulf, Julie M., and Scott Waggoner, 2010. "Corporate strategy at Berkshire Partners." Harvard Business School Case no. 9-710-414.

Zingales, Luigi, 1995. "Insider ownership and the decision to go public." Review of Economic Studies, 62, 425-448.

Zingales, Luigi, 2015. "Presidential address: Does finance benefit society?" Journal of Finance, 70, 1327-1363. 
Table 1. Market Conditions and Private Equity Buyout Frequency by Deal Type, Quarterly Data, 1980-2013

We regress 100 times the natural log of (type-specific PE buyout count) in quarter $t$ on deal-type indicators interacted with market conditions at buyout close (top panel) and over the following two years (bottom panel), while controlling for deal type and a linear time trend. To characterize contemporaneous market conditions for buyouts that close in quarter $t$, we consider whether the credit spread in $t$ is above or below its sample median value and whether real GDP growth from $t-4$ to $t$ is above or below its median. To characterize the evolution of market conditions over the next two years, we consider whether the change in the credit spread and real GDP from quarter $t$ to $t+8$ are above or below their median values. After dropping quarter-type cells with no buyouts, each regression has 454 observations. In unreported results, we obtain very similar results when using the inverse hyperbolic sine transformation of the buyout count and retaining observations with zero buyouts. $* * * \mathrm{p}<0.01, * * \mathrm{p}<0.05, * \mathrm{p}<0.1$.

Dependent Variable: $100 * \ln$ (type-specific buyout count in quarter $t$ )

Coefficient on Market Conditions (row) interacted

with Deal-Type Indicator (column)

Equality of

Coefficients

Market Conditions

Private to Private

Public to Private

Divisional Sales

Secondary Sale

$\mathrm{R}^{\wedge} 2$

( $p$-value)

A. At Buyout Close

High GDP Growth

$28.2^{* * *}$

[9.5]

Wide Credit Spread

$-20.7^{* *}$

$66.0 * * *$

[16.1]

$-26.6^{*}$

[14.7]

$41.2 * * *$

[15.6]

$-18.1$

1.7

B. Over Next 2 Years

High GDP Growth

11.9

$44.9 * * *$

[14.9]

[14.4]

$-24.9^{*}$

0.74

0.000

[15.0]

0.019

[11.2]

[14.7]

[16.3]

$-40.7 * * *$

Widening Credit 


\section{Table 2. Summary Statistics for Private Equity Buyouts Matched to Census Micro Data}

Panel A considers all matched targets in our 1980-2013 sample period. The first row in Panel B considers all matched targets in the 1980-2011 period, the second row excludes those matched using EIN numbers only, and the third row further restricts attention to "Two-year continuers," which include target firms that shut down all establishments by the second year after the buyout year. Panel C considers the same 1980-2003 period as the analysis sample in Davis et al. (2014).

\begin{tabular}{lccc} 
& $\begin{array}{c}\text { Number of } \\
\text { Matched Buyouts } \\
\text { (Target Firms) }\end{array}$ & $\begin{array}{c}\text { Number of Target } \\
\text { Establishments in } \\
\text { the Buyout Year }\end{array}$ & $\begin{array}{c}\text { Employment at Target } \\
\text { Establishments in the } \\
\text { Buyout Year }\end{array}$ \\
\hline $\begin{array}{ccc}\text { A. All, 1980-2013 } \\
\text { Private-to-private }\end{array}$ & 6,000 & 177,000 & $6,890,000$ \\
Public-to-private & 2,600 & 42,000 & $1,800,000$ \\
Divisional Sales & 600 & 67,000 & $2,130,000$ \\
Secondary Sales & 1,300 & 25,000 & $1,120,000$ \\
Unknown Type & 1,300 & 31,000 & $1,280,000$ \\
& 200 & 12,000 & 560,000 \\
B. All, 1980-2011 & 5,100 & 164,000 & \\
After excluding EIN cases & 4,500 & 144,000 & $6,400,000$ \\
Two-year continuers, & 3,600 & 127,000 & $5,690,000$ \\
Private-to-private & 1,800 & 32,000 & $4,970,000$ \\
Public-to-private & 500 & 58,000 & $1,450,000$ \\
Divisional Sales & 400 & 11,000 & $1,800,000$ \\
Secondary Sales & 800 & 20,000 & 470,000 \\
Unknown Type & 100 & 6,000 & 920,000 \\
& & & 330,000 \\
C. All, 1980-2003 & 1,800 & 69,000 & $2,990,000$ \\
After excluding EIN cases & 1,500 & 59,000 & $2,630,000$ \\
Two-year continuers, & 1,200 & 49,500 & $2,210,000$ \\
Private-to-private & 600 & 21,000 & 900,000 \\
Public-to-private & 200 & 16,000 & 690,000 \\
Divisional Sales & 200 & 5,000 & 210,000 \\
Secondary Sales & 150 & 3,600 & 180,000 \\
Unknown Type & 80 & 3,900 & 230,000 \\
\hline
\end{tabular}


Table 3. Estimated Buyout Effects on Employment, Job Reallocation, and Productivity

The sample contains matched two-year continuers that underwent private equity buyouts from 1980 to 2011 and control firms in the same cells defined by the full cross product of firm age, firm size, industry, multi-unit status and buyout year. Some firms serve as controls for more than one buyout type. Outcome measures are (approximate) percentage amounts from the buyout year $t$ to $t+2$. Each reported effect is the coefficient estimate [standard error] on a buyout indicator in a separate weighted least-squares regression that includes a full set of cell-level fixed effects and controls for pre-buyout growth histories. See Appendix B for an explanation of how we weight observations. Results for "All Margins" include the contribution of post-buyout acquisitions and divestitures, while results for "Organic Margins" exclude them. Reallocation measures are computed from establishment-level employment changes at the firm. The final column presents the p-value from F-tests of the equality of the coefficients of the four buyout type variables. Huber-White robust standard errors in brackets. $* * * \mathrm{p}<0.01, * * \mathrm{p}<0.05, * \mathrm{p}<0.1$

\begin{tabular}{|c|c|c|c|c|c|c|c|c|c|c|c|}
\hline \multirow[b]{2}{*}{ Dependent Variable } & \multicolumn{2}{|c|}{ All Buyouts } & \multicolumn{2}{|c|}{ Private-to-private } & \multicolumn{2}{|c|}{ Public-to-private } & \multicolumn{2}{|c|}{ Divisional } & \multicolumn{2}{|c|}{ Secondary } & \multirow{2}{*}{$\begin{array}{c}\text { p-Value, } \\
\text { F-test }\end{array}$} \\
\hline & Effect & $R^{2}$ & Effect & $\mathrm{R}^{2}$ & Effect & $R^{2}$ & Effect & $\mathrm{R}^{2}$ & Effect & $\mathrm{R}^{2}$ & \\
\hline $\begin{array}{l}\text { A. Employment Growth, } \\
\text { All Margins }\end{array}$ & $\begin{array}{l}-1.4 \\
{[2.2]}\end{array}$ & 0.32 & $\begin{array}{c}12.8 * * * \\
{[2.5]}\end{array}$ & 0.37 & $\begin{array}{c}-12.6 * * * \\
{[2.9]}\end{array}$ & 0.38 & $\begin{array}{c}-11.5 * * \\
{[4.7]}\end{array}$ & 0.32 & $\begin{array}{c}9.9 * * * \\
{[2.5]}\end{array}$ & 0.32 & 0.000 \\
\hline Organic Margins & $\begin{array}{c}-4.4^{* *} \\
{[1.9]} \\
\end{array}$ & 0.29 & $\begin{array}{c}3.1^{* *} \\
{[1.5]}\end{array}$ & 0.33 & $\begin{array}{c}-10.0 * * * \\
{[2.4]}\end{array}$ & 0.39 & $\begin{array}{c}-16.0 * * * \\
{[4.2]}\end{array}$ & 0.29 & $\begin{array}{c}6.1 * * * \\
{[2.3]}\end{array}$ & 0.31 & 0.000 \\
\hline $\begin{array}{l}\text { B. Job Reallocation, } \\
\text { All Margins }\end{array}$ & $\begin{array}{c}11.5^{* * *} \\
{[1.8]}\end{array}$ & 0.39 & $\begin{array}{c}11.7 * * * \\
{[2.7]}\end{array}$ & 0.39 & $\begin{array}{c}9.6 * * * \\
{[2.3]}\end{array}$ & 0.45 & $\begin{array}{c}19.4 * * * \\
{[4.5]}\end{array}$ & 0.43 & $\begin{array}{c}9.4 * * * \\
{[2.7]}\end{array}$ & 0.39 & 0.638 \\
\hline Organic Margins & $\begin{array}{c}7.1 * * * \\
{[1.8]}\end{array}$ & 0.39 & $\begin{array}{c}2.5 \\
{[1.9]}\end{array}$ & 0.44 & $\begin{array}{c}6.2 * * * \\
{[2.0]} \\
\end{array}$ & 0.44 & $\begin{array}{c}17.1 * * * \\
{[4.4]}\end{array}$ & 0.41 & $\begin{array}{c}6.4^{* *} \\
{[2.8]} \\
\end{array}$ & 0.41 & 0.032 \\
\hline $\begin{array}{l}\text { C. Excess Reallocation, } \\
\text { All Margins }\end{array}$ & $\begin{array}{c}5.0 * * * \\
{[1.1]}\end{array}$ & 0.40 & $\begin{array}{c}5.5^{* *} \\
{[2.3]}\end{array}$ & 0.42 & $\begin{array}{c}1.7 \\
{[1.6]}\end{array}$ & 0.39 & $\begin{array}{c}10.0 * * * \\
{[1.9]}\end{array}$ & 0.44 & $\begin{array}{c}7.1 * * * \\
{[2.4]}\end{array}$ & 0.45 & 0.175 \\
\hline Organic Margins & $\begin{array}{c}0.6 \\
{[1.5]}\end{array}$ & 0.35 & $\begin{array}{l}-3.8 \\
{[3.4]}\end{array}$ & 0.40 & $\begin{array}{l}-1.7 \\
{[1.8]}\end{array}$ & 0.36 & $\begin{array}{c}7.6 * * * \\
{[2.3]} \\
\end{array}$ & 0.37 & $\begin{array}{c}4.2 \\
{[2.8]}\end{array}$ & 0.40 & 0.030 \\
\hline Observations (000s) & 6,40 & & 3,9 & & 400 & & 2,30 & & 600 & & \\
\hline $\begin{array}{r}\text { D. Labor } \\
\text { Productivity }\end{array}$ & $\begin{array}{l}7.5^{*} \\
{[4.1]}\end{array}$ & 0.47 & $\begin{array}{c}14.7^{* * *} \\
{[4.5]}\end{array}$ & 0.44 & $\begin{array}{c}14.3 \\
{[11.1]}\end{array}$ & 0.62 & $\begin{array}{l}-5.0 \\
{[7.6]}\end{array}$ & 0.38 & $\begin{array}{c}0.7 \\
{[5.6]}\end{array}$ & 0.43 & 0.080 \\
\hline Observations (000s) & 911 & & 41 & & 17 & & 620 & & 40 & & \\
\hline
\end{tabular}


Table 4. How Buyout Effects Vary with Macroeconomic and Credit Conditions at the Close

This table considers the same outcome measures, estimation method and samples as Table 3, but we expand the regression specification to include market conditions at the buyout close and its interaction with the buyout indicator. We measure market conditions using the Credit Spread or GDP Growth variable defined in the text and consider them in separate regressions. For each outcome measure, the table entries report the estimated coefficient on the interaction variable, its standard error, and the coefficient multiplied by the standard deviation of the interaction variable, which ranges from 3.1 to 3.5 Credit Spread across samples and from 1.6 to 1.9 for GDP Growth. Huber-White robust standard errors in brackets. $* * * \mathrm{p}<0.01, * * \mathrm{p}<0.05, * \mathrm{p}<0$.

\section{Interaction Variable}

\begin{tabular}{|c|c|c|c|}
\hline \multirow{3}{*}{ Dependent Variable } & & \\
\hline & & Credit & GDP \\
\hline & & Spread & Growth \\
\hline \multirow{3}{*}{$\begin{array}{c}\text { A. Employment Growth, } \\
\text { All Margins }\end{array}$} & Coefficient & 0.28 & -0.24 \\
\hline & [St. Error] & [0.77] & {$[1.28]$} \\
\hline & Unit S.D. Effect & 1.0 & -0.4 \\
\hline \multirow{3}{*}{ Organic Margins } & Coefficient & -0.12 & 0.14 \\
\hline & [St. Error] & {$[0.62]$} & [1.08] \\
\hline & Unit S.D. Effect & -0.4 & 0.3 \\
\hline \multirow{3}{*}{$\begin{array}{l}\text { B. Excess Reallocation, } \\
\text { All Margins }\end{array}$} & Coefficient & $1.32 * * *$ & -0.66 \\
\hline & [St. Error] & {$[0.45]$} & [0.69] \\
\hline & Unit S.D. Effect & 4.6 & -1.2 \\
\hline \multirow{3}{*}{$\begin{array}{l}\text { C. Labor } \\
\text { Productivity }\end{array}$} & Coefficient & $5.86 * *$ & -3.58 \\
\hline & [St. Error] & {$[2.56]$} & {$[4.47]$} \\
\hline & Unit S.D. Effect & 20.3 & -6.8 \\
\hline
\end{tabular}




\section{Table 5. How Buyout Effects Vary with the Credit Spread Change in the Two Years after the Buyout}

The outcome measures, samples, weighting method and regression specifications in this table follow Table 3 except for two extra explanatory variables in each regression: the change in the credit spread in the two years after buyout close and its interaction with the buyout indicator. For each outcome measure, table entries report the estimated coefficient on the interaction variable, its estimated standard error, and the coefficient multiplied by the sample standard deviation of the Credit Spread. This standard deviation ranges from 4.3 to 4.9 across the regression samples. The final column presents the p-value from F-tests of the equality of the coefficients of the three reported buyout type variables. Huber-White robust standard errors in brackets. $* * * \mathrm{p}<0.01, * * \mathrm{p}<0.05, * \mathrm{p}<0$.

\begin{tabular}{|c|c|c|c|c|c|c|}
\hline \multicolumn{2}{|l|}{ Dependent Variable } & $\begin{array}{c}\text { All } \\
\text { Buyouts }\end{array}$ & $\begin{array}{l}\text { Private-to- } \\
\text { private }\end{array}$ & $\begin{array}{l}\text { Public-to- } \\
\text { private }\end{array}$ & Divisional & $\begin{array}{c}\text { p-Value, } \\
\text { F-test }\end{array}$ \\
\hline \multirow{3}{*}{$\begin{array}{l}\text { A. Employment Growth, } \\
\text { All Margins }\end{array}$} & Coefficient & $-0.57 *$ & $-1.04 * *$ & -0.64 & 0.62 & 0.083 \\
\hline & [St. Error] & {$[0.30]$} & {$[0.48]$} & {$[0.39]$} & {$[0.66]$} & \\
\hline & Unit S.D. Effect & -2.8 & -4.9 & -2.6 & 2.1 & \\
\hline \multirow{3}{*}{ Organic Margins } & Coefficient & -0.30 & 0.25 & -0.51 & 0.36 & 0.003 \\
\hline & [St. Error] & {$[0.26]$} & {$[0.25]$} & {$[0.34]$} & {$[0.56]$} & \\
\hline & Unit S.D. Effect & -1.5 & 1.2 & -2.1 & 1.2 & \\
\hline \multirow{3}{*}{$\begin{array}{l}\text { Excess Reallocation, } \\
\text { All Margins }\end{array}$} & Coefficient & $-0.64 * * *$ & -0.19 & $-0.49 *$ & $-1.14 * *$ & 0.127 \\
\hline & [St. Error] & {$[0.18]$} & {$[0.22]$} & {$[0.25]$} & {$[0.46]$} & \\
\hline & Unit S.D. Effect & -3.1 & -0.9 & -2.0 & -3.9 & \\
\hline \multirow{3}{*}{$\begin{array}{l}\text { C. Labor } \\
\text { roductivity }\end{array}$} & Coefficient & -1.43 & $1.70^{*}$ & $-4.94 * *$ & $-1.83^{* *}$ & 0.014 \\
\hline & [St. Error] & {$[0.91]$} & {$[1.01]$} & {$[2.18]$} & {$[0.83]$} & \\
\hline & Unit S.D. Effect & -6.1 & 9.2 & -25.7 & -4.6 & \\
\hline
\end{tabular}




\section{Table 6. How Buyout Effects Vary with the GDP Growth Rate in the Two Years after the Buyout}

The outcome measures, samples, weighting method and regression specifications in this table follow Table 3 except for two extra explanatory variables in each regression: the GDP Growth Rate in the two years the buyout close and its interaction with the buyout indicator. For each outcome measure, table entries report the estimated coefficient on the buyout-GDP interaction variable, its standard error, and the coefficient multiplied by the sample standard deviation of the GDP Growth Rate, which ranges from 3.4 to 3.6 across the regression samples. The final column presents the p-value from F-tests of the equality of the coefficients of the three reported buyout type variables. Huber-White robust standard errors in brackets. $* * * \mathrm{p}<0.01, * * \mathrm{p}<0.05, * \mathrm{p}<0$.

\begin{tabular}{|c|c|c|c|c|c|c|}
\hline Dependent Variable & & $\begin{array}{c}\text { All } \\
\text { Buyouts }\end{array}$ & $\begin{array}{l}\text { Private-to- } \\
\text { private }\end{array}$ & $\begin{array}{l}\text { Public-to- } \\
\text { private }\end{array}$ & Divisional & $\begin{array}{c}\mathrm{p} \text {-Value, } \\
\text { F-test } \\
\end{array}$ \\
\hline \multirow{3}{*}{$\begin{array}{l}\text { A. Employment Growth, } \\
\text { All Margins }\end{array}$} & Coefficient & $0.96 *$ & 0.28 & -0.05 & 1.82 & 0.106 \\
\hline & [St. Error] & {$[0.54]$} & {$[0.67]$} & {$[0.72]$} & [1.14] & \\
\hline & Unit S.D. Effect & 3.2 & 1.0 & -0.1 & 6.3 & \\
\hline \multirow{3}{*}{ Organic Margins } & Coefficient & 0.34 & $-1.21 * * *$ & -0.04 & 1.18 & 0.000 \\
\hline & [St. Error] & {$[0.40]$} & [0.34] & {$[0.53]$} & {$[0.84]$} & \\
\hline & Unit S.D. Effect & 1.1 & -4.2 & -0.1 & 4.1 & \\
\hline \multirow{3}{*}{$\begin{array}{l}\text { B. Excess Reallocation, } \\
\text { All Margins }\end{array}$} & Coefficient & $0.88 * * *$ & -0.56 & $1.03^{* * *}$ & $1.67^{* *}$ & 0.064 \\
\hline & [St. Error] & [0.28] & {$[0.40]$} & {$[0.35]$} & {$[0.74]$} & \\
\hline & Unit S.D. Effect & 3.0 & -1.9 & 2.8 & 5.8 & \\
\hline \multirow{3}{*}{$\begin{array}{l}\text { C. Labor } \\
\text { Productivity }\end{array}$} & Coefficient & 0.98 & $-2.29 *$ & $4.86^{*}$ & $2.68^{*}$ & 0.216 \\
\hline & [St. Error] & [1.17] & [1.23] & {$[2.65]$} & {$[1.55]$} & \\
\hline & Unit S.D. Effect & 3.6 & -10.4 & 16.4 & 10.0 & \\
\hline
\end{tabular}




\section{Table 7. How Buyout Effects Vary with NBER Recessions}

This table considers the same outcome measures, estimation method, and samples as Table 4 and the first columns of Tables 5 and 6 , but we modify the regression specification (2) in the paper to instead include interactions between the buyout indicator and (a) the presence of an NBER-defined recession during the year of the buyout close (column 1) or (b) the inception of such a recession within two years of the transaction (column 2) instead of interactions with market conditions using the Credit Spread or GDP Growth variable. For each outcome measure, the table entries report the estimated coefficient on the interaction variable and its standard error. HuberWhite robust standard errors in brackets. $* * * \mathrm{p}<0.01, * * \mathrm{p}<0.05, * \mathrm{p}<0$.

\begin{tabular}{cccc} 
Dependent Variable & & $\begin{array}{c}\text { Recession } \\
\text { at Close }\end{array}$ & $\begin{array}{c}\text { Recession } \\
\text { Afterwards }\end{array}$ \\
\hline \hline A. Employment Growth, & Coefficient & $10.75^{* * *}$ & $-10.85^{* * *}$ \\
All Margins & [St. Error] & {$[3.19]$} & {$[3.87]$} \\
\hline Organic Margins & Coefficient & $11.57^{* * *}$ & $-7.36^{* * *}$ \\
& [St. Error] & {$[2.67]$} & {$[3.17]$} \\
\hline B. Excess Reallocation, & Coefficient & 2.08 & $-12.11^{* * *}$ \\
All Margins & [St. Error] & {$[3.25]$} & {$[3.82]$} \\
\hline C. Labor & Coefficient & -5.82 & -12.82 \\
Productivity & [St. Error] & {$[6.51]$} & {$[9.61]$} \\
\hline
\end{tabular}


Table 8. The Impact of Excluding Deals Most Impacted by the Global Financial Crisis

This table considers the same outcome measures, estimation method, and samples as Table 4, and the first columns of Tables 5 and 6 , but we modify the sample by excluding observations from 2007. We measure market conditions using the Credit Spread or GDP Growth variable defined in the text and consider them in separate regressions. For each outcome measure, the table entries report the estimated coefficient on the interaction variable and its standard error. Huber-White robust standard errors in brackets. $* * * p<0.01, * * p<0.05, *$ $\mathrm{p}<0$.

\begin{tabular}{|c|c|c|c|c|c|}
\hline \multirow[b]{2}{*}{ Dependent Variable } & & \multicolumn{2}{|c|}{ Table 4} & \multirow{2}{*}{$\begin{array}{l}\text { Table } 5 \\
\text { Credit } \\
\text { Spread }\end{array}$} & \multirow{2}{*}{$\begin{array}{c}\text { Table } 6 \\
\text { GDP } \\
\text { Growth }\end{array}$} \\
\hline & & $\begin{array}{l}\text { Credit } \\
\text { Spread }\end{array}$ & $\begin{array}{c}\text { GDP } \\
\text { Growth }\end{array}$ & & \\
\hline $\begin{array}{l}\text { A. Employment Growth, } \\
\text { All Margins }\end{array}$ & $\begin{array}{l}\text { Coefficient } \\
\text { [St. Error] }\end{array}$ & $\begin{array}{l}-0.12 \\
{[0.80]}\end{array}$ & $\begin{array}{c}0.93 \\
{[0.96]}\end{array}$ & $\begin{array}{l}-1.71 \\
{[1.21]}\end{array}$ & $\begin{array}{c}0.08 \\
{[0.68]}\end{array}$ \\
\hline Organic Margins & $\begin{array}{l}\text { Coefficient } \\
\text { [St. Error] }\end{array}$ & $\begin{array}{l}-0.40 \\
{[0.60]}\end{array}$ & $\begin{array}{l}1.35^{\star *} \\
{[0.66]}\end{array}$ & $\begin{array}{l}-1.34 \\
{[1.03]}\end{array}$ & $\begin{array}{l}-0.66 \\
{[0.44]}\end{array}$ \\
\hline $\begin{array}{l}\text { B. Excess Reallocation, } \\
\text { All Margins }\end{array}$ & $\begin{array}{l}\text { Coefficient } \\
\text { [St. Error] }\end{array}$ & $\begin{array}{c}0.51 \\
{[0.46]}\end{array}$ & $\begin{array}{l}-0.59 \\
{[0.43]}\end{array}$ & $\begin{array}{c}-1.25^{\star *} \\
{[0.58]}\end{array}$ & $\begin{array}{l}0.86^{\star *} \\
{[0.44]}\end{array}$ \\
\hline $\begin{array}{l}\text { C. Labor } \\
\text { Productivity }\end{array}$ & $\begin{array}{l}\text { Coefficient } \\
\text { [St. Error] }\end{array}$ & $\begin{array}{l}4.71^{*} \\
{[2.51]}\end{array}$ & $\begin{array}{l}-0.29 \\
{[1.66]}\end{array}$ & $\begin{array}{l}-8.02 \\
{[4.89]}\end{array}$ & $\begin{array}{l}-1.92^{*} \\
{[0.98]}\end{array}$ \\
\hline
\end{tabular}


Table 9. Blinder-Oaxaca Decompositions. The sample contains matched two-year continuers that underwent PE buyouts from 1980 to 2011 with sponsors that can be linked to fund-level commercial data sources. For each buyout, we compute the outcome measure from buyout year $t$ to $t+2$ for the target firm minus the corresponding average value for control firms in the same cell defined by the full cross product of firm-age category, firm-size category, industry, multi-unit status, and buyout year. Panel A presents coefficients from a regression of the outcome measure on a dummy for being above the median in (a) GDP growth in the two years after the buyout or (b) the credit spread at deal close. Panel B presents Blinder-Oaxaca decompositions of the difference between high and low values of the market conditions variable. The decompositions are based on separate regressions of the outcome measure on buyout type indicators and PE sponsor characteristics in subsamples defined by high and low values of the market conditions variable. See text for the full variable list. We use buyouts in the high-value subsample as the reference group when implementing the decomposition. ${ }^{*} * * \mathrm{p}<0.01$, $* * \mathrm{p}<0.05, * \mathrm{p}<0.1$.

\begin{tabular}{|c|c|c|c|}
\hline & \multicolumn{3}{|c|}{ Outcome Measure (Target Minus Average of Controls) } \\
\hline & $\begin{array}{l}\text { Employment } \\
\text { Growth Rate }\end{array}$ & $\begin{array}{c}\text { Excess } \\
\text { Reallocation Rate }\end{array}$ & $\begin{array}{l}\text { Productivity } \\
\text { Growth }\end{array}$ \\
\hline \multicolumn{4}{|l|}{ A. Simple regression fit to all buyouts in sample } \\
\hline \multirow{2}{*}{$\begin{array}{l}\text { Coefficient on a Dummy for High GDP Growth Post-Buyout - the } \\
\text { "High-Low Difference" }\end{array}$} & $7.14^{* * *}$ & $3.60^{* * *}$ & \\
\hline & {$[1.56]$} & {$[0.74]$} & \\
\hline \multirow{2}{*}{$\begin{array}{l}\text { Coefficient on a Dummy for High Credit Spread at Close - the } \\
\text { "High-Low Difference" }\end{array}$} & & & $13.85^{* *}$ \\
\hline & & & [6.02] \\
\hline \multicolumn{4}{|l|}{ B. Blinder-Oaxaca Decompositions } \\
\hline \multirow{2}{*}{$\begin{array}{l}\text { (1) Contribution of changes in buyout types and PE sponsor } \\
\text { characteristics to the High-Low difference in Panel A }\end{array}$} & 1.81 & 0.77 & $12.99^{* * *}$ \\
\hline & [1.57] & [0.63] & [4.01] \\
\hline \multirow{2}{*}{$\begin{array}{l}\text { (2) Contribution of changes in coefficients on buyout types and PE } \\
\text { sponsor characteristics to the High-Low difference in Panel A }\end{array}$} & $6.10^{* * *}$ & $3.22^{* * *}$ & $15.37^{*}$ \\
\hline & {$[1.76]$} & {$[0.79]$} & {$[9.00]$} \\
\hline \multirow{2}{*}{$\begin{array}{l}\text { (3) Contribution of interactions effects to the High-Low difference } \\
\text { in Panel A }\end{array}$} & 0.77 & -0.39 & -14.52 \\
\hline & [1.64] & {$[0.70]$} & [8.89] \\
\hline Observation Counts & 3,900 & 3,900 & 500 \\
\hline
\end{tabular}


Table 10. The Persistence of Buyout Effects on Employment Growth at the Level of Private Equity Groups. The unit of observation for the regressions in this table is the average cell-adjusted target outcome for the buyouts of a given private equity sponsor in a particular five-year period $(1980-84,1985-89, \ldots)$. Results for "Total Employment Growth" include the contribution of post-buyout acquisitions and divestitures, while results for "Organic Employment Growth" do not. See text for a full description of the explanatory variables. Huber-White robust standard errors in brackets. $* * * \mathrm{p}<0.01, * * \mathrm{p}<0.05,{ }^{*} \mathrm{p}<0.1$.

\begin{tabular}{|c|c|c|c|c|c|c|c|c|c|c|}
\hline & \multicolumn{5}{|c|}{ Average Total Employment Growth Rate } & \multicolumn{5}{|c|}{ Average Organic Employment Growth Rate } \\
\hline & $(1)$ & $(2)$ & (3) & $(4)$ & $(5)$ & (6) & (7) & $(8)$ & (9) & $(10)$ \\
\hline \multirow{2}{*}{$\begin{array}{l}\text { Lagged Average } \\
\text { Employment Growth }\end{array}$} & 0.0747 & 0.0744 & 0.0753 & -0.0989 & $-0.3045^{* * *}$ & & & & & \\
\hline & {$[0.0461]$} & {$[0.0462]$} & {$[0.0462]$} & {$[0.3545]$} & {$[0.0747]$} & & & & & \\
\hline \multirow{2}{*}{$\begin{array}{l}\text { Lagged Average Organic } \\
\text { Growth }\end{array}$} & & & & & & $0.1229^{* * *}$ & $0.1226^{* * *}$ & $0.1226^{\star * *}$ & 0.0504 & $-0.3174^{\star * *}$ \\
\hline & & & & & & {$[0.0465]$} & {$[0.0466]$} & {$[0.0464]$} & {$[0.3754]$} & {$[0.0842]$} \\
\hline \multirow{2}{*}{$\begin{array}{l}\text { \# of Buyouts in Current } \\
\text { Five-Year Period }\end{array}$} & & $-0.0387^{* * *}$ & & & & & $-0.0361^{* * *}$ & & & \\
\hline & & {$[0.0132]$} & & & & & {$[0.0117]$} & & & \\
\hline \multirow{2}{*}{$\begin{array}{l}\text { Change in \# of Buyouts } \\
\text { from Previous to Current } \\
\text { Five-Year Period }\end{array}$} & & & -0.4234 & & & & & -1.292 & & \\
\hline & & & [0.6443] & & & & & {$[0.8403]$} & & \\
\hline \multirow{2}{*}{$\begin{array}{l}\text { Time trend X Lagged } \\
\text { Growth }\end{array}$} & & & & 0.3773 & & & & & 0.1569 & \\
\hline & & & & [0.8043] & & & & & {$[0.8526]$} & \\
\hline $\mathrm{R}^{2}$ & 0.0128 & 0.0132 & 0.013 & 0.0131 & 0.7485 & 0.0283 & 0.0288 & 0.0307 & 0.0284 & 0.7725 \\
\hline Period fixed effects & YES & YES & YES & YES & YES & YES & YES & YES & YES & YES \\
\hline PE group fixed effects & & & & & YES & & & & & YES \\
\hline
\end{tabular}


Table 11. The Impact of Scaling at the PE Group Level on Employment Growth of Target Firms. The sample consists of matched two-year continuers that underwent private equity buyouts from 1980 to 2011 and control firms in the same cells defined by the full cross product of firm age, firm size, industry, multi-unit status and buyout year. Some firms serve as controls for more than one buyout type. The dependent variables are percentage changes from the buyout year $t$ to $t+2$ in "Total Employment Growth," which includes the contribution of post-buyout acquisitions and divestitures, and "Organic Employment Growth," which excludes them. Each reported effect is the coefficient estimate [standard error] on a buyout dummy interacted with the indicated group-level scaling measure. See text for a full description of the scaling measures. The mean and standard deviation values of the scaling measures pertain to the set of all buyouts from 1980 to 2011 for which we could identify the PE sponsor and collect information about the sponsor. This set is larger than the set of buyouts in the regression samples, which also involve matching to Census data on targets and controls. We estimate a separate weighted least-squares regression for each column and report Huber-White robust standard errors in brackets. $* * * \mathrm{p}<0.01, * *$ $\mathrm{p}<0.05, * \mathrm{p}<0.1$.

\begin{tabular}{|c|c|c|c|c|c|c|c|c|}
\hline \multirow{4}{*}{$\begin{array}{l}\text { Scaling Measure for the Private Equity } \\
\text { Group that Sponsored the Buyout } \\
\text { Funds raised in prior five years, } \\
\text { normalized (Mean }=0.0047 \text {, S.D. }=0.0138 \text { ) }\end{array}$} & \multicolumn{8}{|c|}{ Dependent Variable } \\
\hline & \multicolumn{4}{|c|}{ Total Employment Growth } & \multicolumn{4}{|c|}{ Organic Employment Growth } \\
\hline & $-111.8^{*}$ & & & & $-50.22^{*}$ & & & \\
\hline & {$[58.96]$} & & & & [29.30] & & & \\
\hline \multirow{2}{*}{$\begin{array}{l}\text { Adjusted financial performance of prior } \\
\text { two funds (Mean=0.25, S.D. }=1.12 \text { ) }\end{array}$} & & $-7.32^{* * *}$ & & & & $-3.97^{* * *}$ & & \\
\hline & & {$[1.66]$} & & & & [0.93] & & \\
\hline \multirow{2}{*}{$\begin{array}{l}\text { Number of Buyouts in Current Five-Year } \\
\text { Period (Mean=6.7, S.D.=8.5) }\end{array}$} & & & $-0.0113^{*}$ & & & & $-0.0122^{* *}$ & \\
\hline & & & {$[0.0066]$} & & & & {$[0.00556]$} & \\
\hline \multirow{2}{*}{$\begin{array}{l}\text { Change in Number of Buyouts from } \\
\text { Previous to Current Five-Year Period } \\
\text { (Mean }=0.43, \text { S.D. }=2.11 \text { ) }\end{array}$} & & & & -0.0709 & & & & -0.356 \\
\hline & & & & {$[0.269]$} & & & & {$[0.236]$} \\
\hline $\mathrm{R}^{2}$ & 0.396 & 0.260 & 0.394 & 0.393 & 0.355 & 0.236 & 0.355 & 0.355 \\
\hline Cell fixed effects & YES & YES & YES & YES & YES & YES & YES & YES \\
\hline Deal type fixed effects & YES & YES & YES & YES & YES & YES & YES & YES \\
\hline $\begin{array}{l}\text { Controls for pre-buyout growth history of } \\
\text { target firm }\end{array}$ & YES & YES & YES & YES & YES & YES & YES & YES \\
\hline
\end{tabular}


Figure 1. Quarterly Buyout Counts by Type, 1980 to 2013

Each panel shows buyout closings for the indicated deal type in quarter $t$, overlaid with the contemporaneous credit spread and the log change in real GDP from t-4 to t. We exclude about 300 buyouts that we cannot classify as to deal type. See Section I.A for an explanation of how we construct our sample of 9,794 leveraged buyouts sponsored by private equity firms.

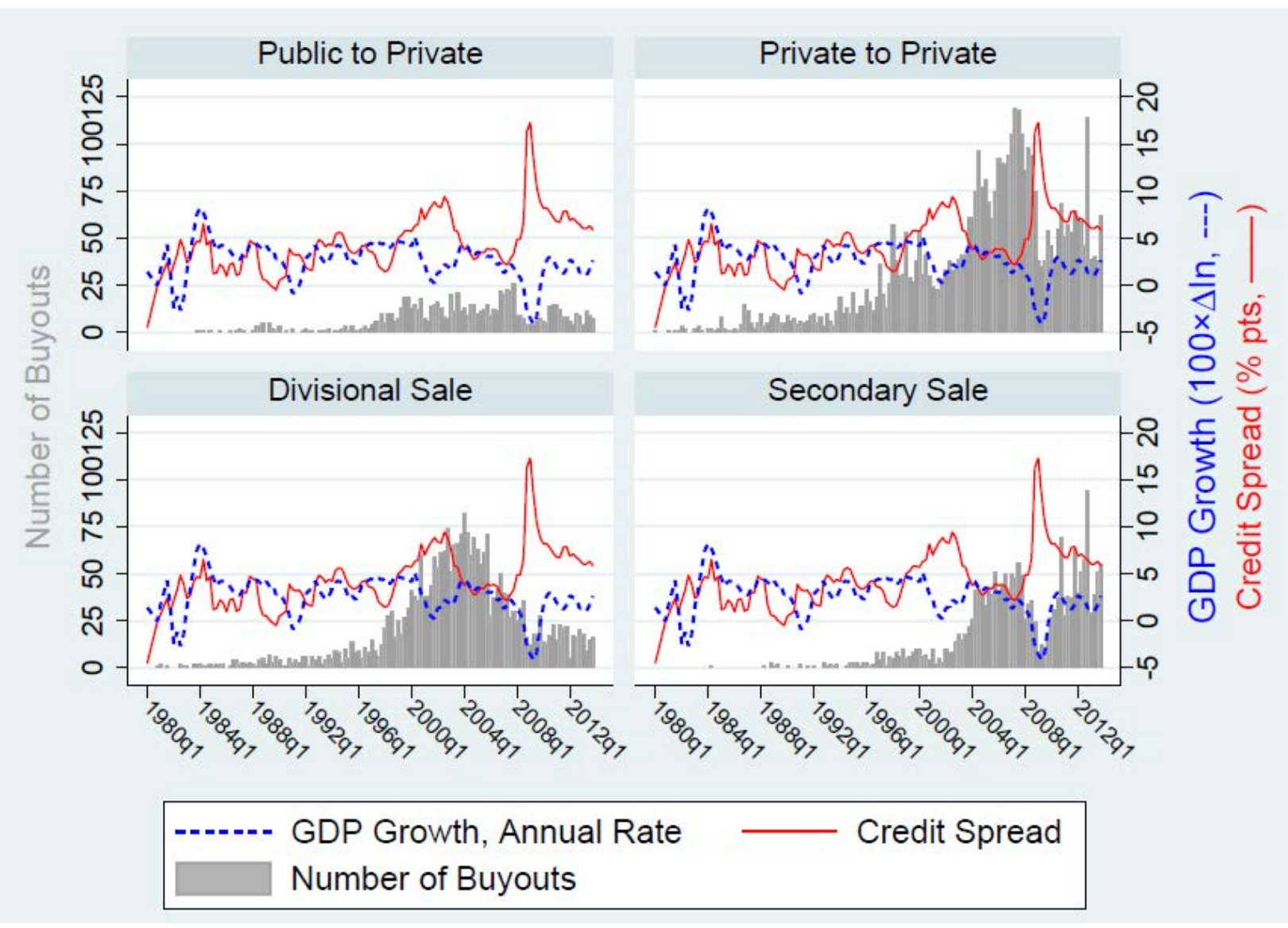


Figure 2. How Buyout Effects Vary with the Post-Buyout Evolution of Market Conditions This figure uses the estimated interaction effects in Tables 5 and 6 to depict how the post-buyout employment growth rate and excess reallocation rate at targets (relative to controls) vary with the post-buyout evolution of market conditions. The center bars show the estimated target-control differential when evaluating at the sample mean of the market condition measures. The other bars show the target-control differential when evaluating the market condition measures at $-2,-1,+1$, and +2 standard deviations below or above their respective sample means.
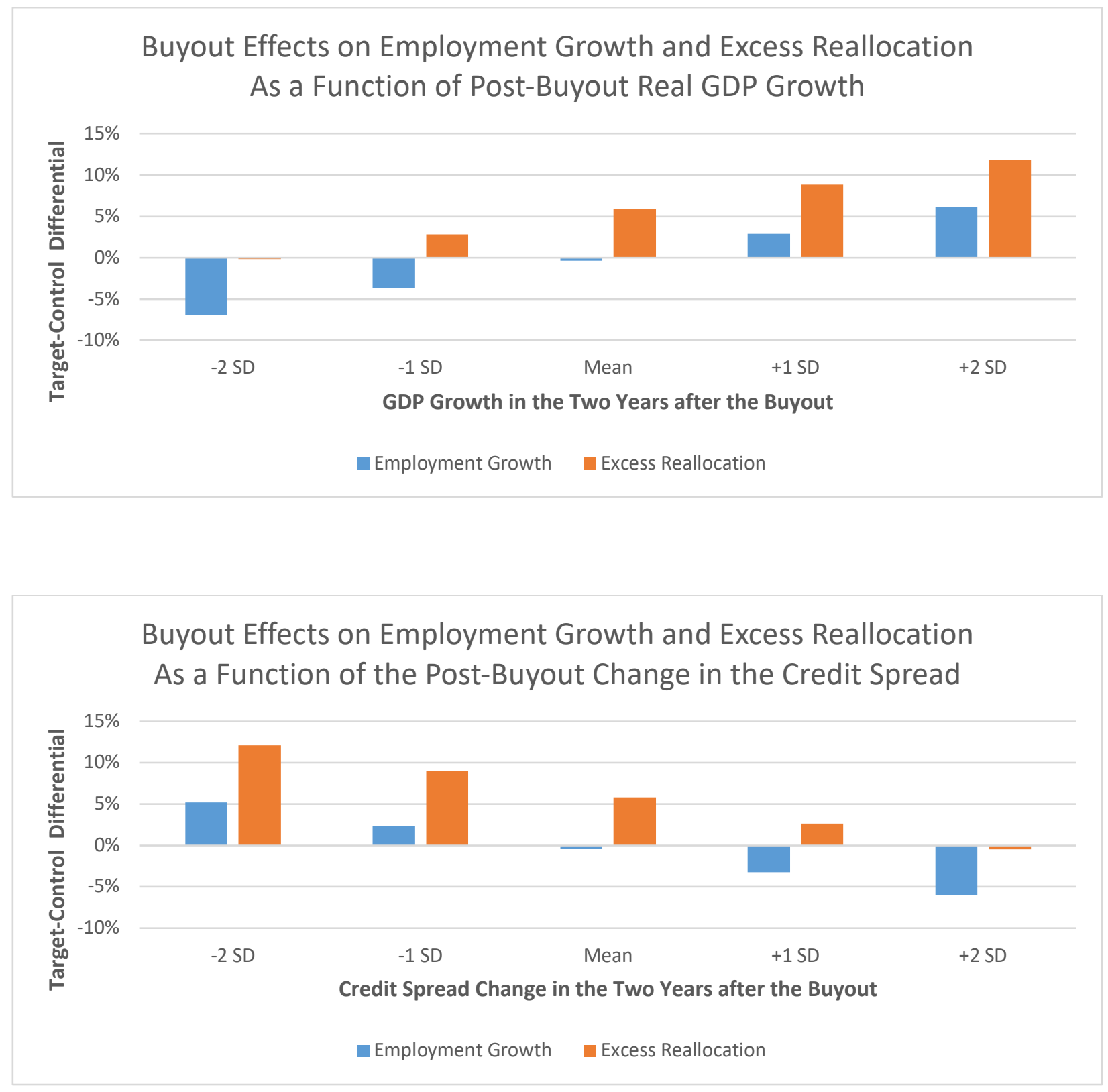


\section{Internet Appendix A: Sample Construction and Matching}

\section{Overview}

We combine information on private equity buyouts from CapitalIQ and other sources with firm-level and establishment-level data held by the U.S. Census Bureau.

Specifically, we undertook a two-part effort, following Strömberg (2008). The first part drew on the CapitalIQ database to create a base sample of PE-sponsored leveraged buyouts. We selected all M\&A transactions in CapitalIQ classified as a "leveraged buyout," "management buyout," or "JV/LBO" (joint venture/leveraged buyout) that closed between January 1, 1980 and December 31, 2013. To this sample, we added all M\&A transactions undertaken by a financial sponsor classified as investing in "buyouts." We excluded management buyouts not sponsored by a PE firm and startup firms backed by venture capitalists. Although CapitalIQ has back-filled its database using various sources since starting its data service in 1999, its coverage remains incomplete in the early years of our sample. For this reason, the second part of our sample construction efforts relied on other databases ${ }^{22}$ the business press, and buyout lists for the 1980s compiled by other researchers.

The overlap between our initial sample of PE buyouts and lists of LBOs with a financial sponsor compiled by other researchers is high. For instance, 62 of the 77 buyouts in Kaplan's (1989) hand-selected sample of LBOs completed between 1980 and 1986 are captured by our CapitalIQ sample, a coverage rate of $81 \%$. We added these 15 missing buyouts to our sample, as we did for other PE buyouts identified using various lists and other sources beyond CapitalIQ.

In the course of our investigations, we discovered that CapitalIQ classifies certain buyout fund transactions as "private placements" rather than acquisitions. In most cases, these private

${ }^{22}$ These include Dealogic, Preqin, and Thomson Reuters. 
placements involve minority stakes or follow-on investments and, hence, are unsuitable for inclusion in our sample. Still, the distinction between buyouts and private placements is not always clear. In addition, some transactions reported as LBO deals were actually venture capital investments, which are not the object of our study. We sought to err on the side of caution by excluding ambiguous transactions and, as a result, may miss some bona fide LBOs.

We also excluded acquisitions not yet completed by the end of 2013, acquisitions of noncontrol stakes (typically associated with growth and venture deals, not classic buyouts), purchases of firms with foreign headquarters, stakes in public companies that remained publicly traded (PIPES), and other misclassified transactions. We identified these transactions through the careful review of text fields in CapitalIQ records and our own detailed research using other commercial databases, securities filings, and media accounts.

We then match these buyout deals to target firms and their establishments in the Census Bureau's comprehensive Business Register (BR). Our basic approach is as follows. First, we use name and address information to match a particular deal to a specific unit in the BR. Because the matching algorithm relies partly on address information, this step identifies a specific establishment owned by the target firm, which is often but not always a headquarters facility. Second, we use the BR link between that establishment's ID and its parent firm ID to identify the target firm in the BR. In most cases, this method identifies the target firm in the BR and all of its establishments.

We describes our matching process in detail below. The process yields a mapping to one or more firms in the BR for about 7,600 of the 9,794 U.S. buyouts that we identified from CapitalIQ and other sources. Of these 7,600 buyouts, about 4,100 match to BR identifiers for a single firm, while the other 3,500 map to identifiers for multiple firms. We resolved about 2,000 of these 3,500 
cases to a unique match, leaving about 6,000 buyouts that we confidently match to a unique firm in the BR in the period from 1980 to 2013 . The approximately 6,000 matched target firms acquired in PE buyouts from 1980 to 2013 operated about 177,000 establishments as of the buyout year and had nearly 7 million workers on their payrolls as of March in the buyout year.

The main reason we cannot confidently resolve the other 1,500 cases to a unique firm in the $\mathrm{BR}$ is because many targets undergo a complex reorganization during the buyout or shortly thereafter. The reorganization can involve the sale of multiple firm components to multiple parties, the emergence of multiple new firm IDs, and the introduction of a complex array of holding company structures. These cases present considerable matching challenges. Rather than include matches of dubious quality, we exclude them from our analysis.

Once matched to the BR, we can identify establishments owned by the target firm as of its buyout year. LBD longitudinal links let us compute employment changes for establishments and firms and track their entry, exit, and ownership changes. We supplement the LBD with firm-level revenue data drawn from the Census BR to obtain a revenue-enhanced version of the LBD (RELBD). The revenue data, available from 1996 to 2013, let us study the impact of PE buyouts on labor productivity, defined as real revenue per worker. About 20 percent of LBD firm-year observations cannot be matched to BR revenue data because firms report income under EINs that fall outside the set of EINs that Census considers part of that firm for employment purposes.

\section{Treatment of Timing Matters}

Given our interest in employment dynamics, the relationship of the LBD employment measure to the timing of PE buyouts requires careful treatment. The LBD reports total employment in the payroll period containing the week of March 12. Accordingly, for buyouts that close before October 1, LBD employment in March of the same calendar year serves as our contemporaneous 
employment measure. We assign buyouts that close on or after October 1 in calendar year $t$ to the LBD employment value in March of $t+1$. October is the natural cutoff because it lies midway between March-to-March employment changes in the LBD. ${ }^{23}$

Henceforth, our references to buyout activity in year $t$ refer to deals that closed from October of calendar year $t-1$ through September of calendar year $t$. In particular, buyouts that closed in October, November or December of 2013 are shifted forward to 2014, beyond the time span covered by our LBD data. As a result, these matched targets are not part of our analysis.

\section{Tracking Firms after the Buyout and Forming Our Analysis Sample}

Of necessity, much of our analysis restricts attention to target firms that we can track after the buyout. While we can readily track establishments over time in the LBD, tracking firms is more challenging for two main reasons: the disappearance of firm identifiers (IDs) and irregularities in Census Bureau tracking of PE targets involved in certain divisional sales. We elaborate on these two reasons in turn.

Firm ID Disappearance. The disappearance of a firm ID in the LBD can occur for various reasons. One is the death of a firm and the closure of all of its establishments. Firm death in this sense presents no problem: we capture such events whether they involve target or control firms. A more difficult situation involves a target firm ID that vanishes in the first or second year after the buyout, even though some of its establishments (as of the buyout year) continue to operate. This situation can arise when the various components of the original firm are acquired by multiple firms. It is inherently difficult to define and measure firm changes when the original legal entity ceases

${ }^{23}$ Fractional-year mistiming of buyout deals is unavoidable when matching to the LBD, given its annual frequency. When buyouts are uniformly distributed over the year, an October cutoff minimizes the mean absolute mistiming gap. See Davis et al. (2018) for additional discussion. As an empirical matter, buyout closing dates are distributed fairly evenly over the calendar year. 
to exist and has no obvious successor. We exclude these cases from our firm-level longitudinal analyses. To reduce the number of observations lost for this reason and other challenges in tracking firms over time, we restrict our longitudinal analyses to the buyout year and the next two years.

Divisional Buyouts. In principle, the annual Company Organization Survey lets Census accurately track the business units involved in divisional sales. However, we discovered divisional sales in which the firm ID of the (new) target firm remained the same as the firm ID of the selling firm. This situation indicates that the new firm created in the course of the divisional buyout did not receive a new firm ID, at least not in a timely manner. This problem does not preclude an establishment-level analysis, because we can often use an alternative identifier - the Employer Identification Number (EIN) - to accurately identify, as of the buyout year, the establishments involved in divisional sales. Unfortunately, EINs are unsuitable for tracking firms through time, because new and acquired establishments may obtain new EINs. Thus, we exclude divisional buyouts from our firm-level longitudinal analyses when the LBD lacks an accurate firm ID for the newly created target firm. We exclude some secondary buyouts for the same reason.

After matching to the BR, we use the Longitudinal Business Database (LBD) - essentially a longitudinal version of the BR - to follow target firms and their establishments over time. We also use the LBD to identify control units (comparable firms and establishments) and to follow them over time as well. In addition, we exploit common alphanumeric identifiers to incorporate other Census micro data for some aspects of our analysis.

The LBD tracks establishments and parent firms using a combination of administrative records and survey collections that include the Company Organization Survey (COS), the Economic Censuses, and the Annual Surveys of Businesses (e.g., the Annual Survey of Manufactures). Information about company structure is incorporated into the LBD by attaching 
firm identifiers to records for establishments. Ownership changes are identified when establishments switch parent firms through mergers, acquisitions, and divestitures.

The Census Bureau assigns a unique firm ID to all establishments under common ownership and control in a given year, including establishments that belong to subsidiaries under control of the parent corporation. This firm ID is distinct from a taxpayer ID such as the employer identification number $(\mathrm{EIN}){ }^{24}$ The relationships among the various IDs are as follows. In any given year, an establishment is uniquely associated with a single taxpayer ID and a single firm ID. Moreover, each taxpayer ID is uniquely associated with a firm ID. For multi-establishment firms, a parent firm ID has multiple affiliated establishment IDs and potentially multiple EINs. Put differently, the EIN as a unit of observation is somewhere between an establishment and a firm.

\section{Matching Buyout Targets to the Business Register (BR)}

From Capital IQ and other sources, we obtain several pieces of information about the acquired entity in a private equity buyout. These pieces include the name of the seller, the name of the acquisition target, the target's address, and the acquisition date. The seller and target are typically the same in whole-firm acquisitions but not in partial-firm acquisitions - for example, when the private equity firm acquires one division of a multi-division company.

We match acquisition targets to firms in the BR using the data matching algorithms that are part of the SAS DQMatch procedure. This is an improved version of the matching algorithm and code we used in Davis et al. (2014). Our DQMatch implementation proceeds through 16 rounds of matching from the strictest criteria (requiring a perfect match on name and address) to progressively looser criteria that allow for fuzzier matching (exact name and fuzzy address, fuzzy

\footnotetext{
${ }^{24}$ The EIN is an employer tax identifier that may or may not change when ownership changes. It is often helpful in matching and tracking target firms and establishments involved in complex reorganizations.
} 
name and exact address, exact name and zip code, etc.) Results from each pass are flagged and the results are stored for use in later analyses. For brevity, we do not discuss the DQMatch matching criteria and the algorithm used to identify matches in detail. ${ }^{25}$ Here, we describe our overall matching strategy, explain how we resolve buyout deals that match to multiple target firm candidates in the $\mathrm{BR}$, and discuss issues that arise in tracking firms over time.

\section{A. A Simple Case}

Suppose a private equity firm acquires firm $\mathrm{A}$ in its entirety during year $t$ and places it under new ownership, possibly with a new name. A simplified version of our matching algorithm in this case works as follows: First, we find an establishment in the BR as of year $t$ located at the target address and owned by a firm with the target name. Second, with this match in hand, we use the firm-establishment links in the BR to identify the full set of establishments operated by the target firm in $t$. From this point, we can measure the activity of the target firm in $t$ and follow the firm (and its establishments) forward from $t$ using the LBD.

\section{B. Challenges that Arise in the Matching Process}

In practice, several challenges arise in the matching process. First, because name and address data are noisy, we may find multiple BR firms that are candidate matches for the acquisition target. ${ }^{26}$ All but one of these candidates, and perhaps all of them, are false positives.

\footnotetext{
${ }^{25}$ Programs to implement the DQMatch algorithm and master batch files to run them are available on the computing cluster servers in the Federal Statistical Research Data Centers.

${ }^{26}$ We use both physical and mailing address from the Business Register when available to generate matches. There is some noise in the addresses for new units in the Business Register that is typically resolved in an Economic Census. Our use of a multi-year window helps to partly overcome this source of noise. However, we did not find that our match rates peaked in Census years, suggesting that business name clarification in Economic Census years is not a big issue for our purposes.
} 
Second, to cope with timing differences between datasets, we search for matches in the BR over a three-year window centered on the buyout year. While this approach can pick up good matches that we would otherwise miss, it can also introduce additional false positive matches. Whenever we have multiple candidate matches, we need some way to resolve to a unique match. When we cannot do so with sufficient confidence, we drop the acquisition target from our analysis.

Third, it can be hard to distinguish the seller firm from the acquisition target in some cases. For example, suppose a private equity firm acquires establishments $e_{1}$ and $e_{2}$ from firm A to form a new firm $\mathrm{B}$ in year $t$. In this case, the activity of establishments $e_{1}$ and $e_{2}$ are associated with both firms $\mathrm{A}$ and $\mathrm{B}$ in $t$, because each firm files tax records that cover $e_{1}$ and $e_{2}$ for part of the year. Thus, when we match the target address to an establishment, that establishment may link to two parent firms in the BR in the buyout year. In this situation as well, we need some way to resolve to a unique match.

Fourth, some private equity buyouts involve complex reorganizations of target entities that lead to the creation of multiple new firms or the piecemeal sale of the target entity to multiple parties. In these cases, even when we successfully match the target address to an establishment and correctly identify that establishment's parent firm, we may identify and track only some of the establishments acquired as part of the buyout. Indeed, there can be multiple true successor firms to the target entity in such cases, and we may capture and track only one of them.

Fifth, another challenge involves divisional buyouts, whereby the private equity firm acquires only part of a multi-division firm. For divisional buyouts, we could not always identify the correct target firm in the BR after matching the deal to a specific establishment. These instances arose because, in some cases, the Census firm ID associated with the matched establishments did not change to reflect the ownership change of the division involved in the buyout deal. We 
identified these problematic cases by observing that the matched target establishment remained affiliated with the parent seller firm even after the buyout. It is our understanding that the Census Bureau on occasion had difficulty tracking the new firm in divisional buyouts because of nonresponse on the COS or other survey instruments.

We thus had two types of divisional cases. The first are those where we could accurately identify the target firm using our main method, and the second where we could not. Even in those cases, we were able to link the matched establishment to at least a part of the target firm through the EIN (taxpayer ID). The complete target firm may or may not be identified in such cases, because the divisional business involved in the buyout may have operated with multiple EINs. In the main text and this appendix, we refer to such cases as EIN cases. In these EIN cases, we can accurately identify a part of the target firm in the buyout year and at least some of the corresponding target establishments, but we cannot be confident that we captured the entire target firm. We exclude EIN cases in our firm-level longitudinal analyses, because the EIN is not suitable for tracking firms over time. For example, if a target firm (i.e., an EIN case) creates or acquires a new establishment, it may obtain a new EIN for that establishment for accounting or tax reasons. In such cases, we would not know that the new establishment is part of the target firm.

\section{How We Proceed}

As explained above, our matching algorithm may initially yield zero, one or multiple candidate matched firms in the BR for a given buyout target. We now provide information about the frequency of these outcomes and describe our process for de-duplicating buyouts that match to multiple Census firm IDs.

No Match 
In about 2000 of the 9794 deals in CapitalIQ, no companies within the BR matched even using the loosest matching criteria. Here and below, we provide rounded figures for counts of matched Census firms because of data disclosure restrictions.

\section{Unique Matches}

As noted above, we search for candidate matches in the BR over a three-year window centered on the buyout year, $t$. First, we select a year $(t-1, t$ or $t+1)$ in the three-year window for the buyout in question. Second, given the year, our algorithm proceeds through 16 rounds using progressively less stringent matching criteria. Third, if we obtain at least one candidate match in a given round, we do not proceed to later rounds for that year. For example, suppose a buyout target matches to a single BR entity in round 4 of our algorithm for year $t$. Even if the target firm matches to other BR entities in later rounds (which involve less stringent criteria), we stop in round 4 for year $t$. This process can lead to one or more candidate matches in each of $t-1, t$ and $t+1$.

For about 4,000 of the 9,794 buyouts that we identified using CapitalIQ and other sources, the process described in the preceding paragraph yields a single match candidate. That is, the process yields at most one candidate in each of $t-1, t$ and $t+1$; and, moreover, when it yields a candidate match in two or three of the years, it is the same firm in each year.

\section{Non-Unique Matches and De-Duplications}

The remaining set of about 3500 buyout deals match to multiple BR entities. This could happen, for example, if we find an exact match on address, but there are multiple firms in a single building with similar company names in the same year. As another example, Census often redefines the target firm's firm ID after the buyout. When it does, we often detect two match candidates within our three-year window centered on the buyout year: one match to the pre-buyout firm ID, and one to the post-buyout firm ID. We use three methods to arrive at a unique match 
between the buyout target and the Census firm ID in these and other cases that yield multiple candidate matches.

The first method for de-duplicating is to check the EINs of the match candidates. For about 25 percent of the duplicates, multiple match candidates have the same EIN. That tells us that each match candidate is owned by the same parent firm, and we proceed on that basis. This method is especially helpful in resolving duplicates that arise when Census changes the firm ID associated with the firm in question within the three-year centered window around the buyout transaction.

The second method for de-duplicating is to exploit the timing pattern of the matches. We consider cases with two candidate matches for the same deal. A common pattern in such cases is that one candidate is the birth of a new firm ID at time $t$ or $t+1$, and the other candidate is a death at time $t-1$ or $t$. In this context, a "birth" is when a new firm ID appears at time $t$ or $t+1$, one that did not appear earlier (in $t-1$ for births in $t$, or $t-1$ and $t$ for births in $t+1$ ). A "death" is when a firm ID disappears in time $t$ or $t+1$. We investigated cases that fit this pattern and determined that they likely reflect PE-precipitated reorganizations. Since these candidate matches satisfy name and address matching criteria, they are unlikely to be spurious. This second step uniquely resolves about 200 additional firm IDs in the BR to a particular target firm in a PE buyout.

If the first and second methods do not yield a unique match, we deploy a third method as follows. First, for the set of candidate matches, rank firm IDs by the strictness of the criteria that generated their inclusion as match candidates. Then create three flags:

- Set Flag 1 to 1 for those firm IDs with the highest rank among the match candidates. If there are two candidate matches, for example, one for year $t+1$ with an exact name and address match and one for year $t$ that matches exactly only on the name, set Flag 1 to 1 for the one that matches exactly on both name and address. 
- Among candidate matches with the highest rank, set Flag 2 to 1 for firm IDs that are present in year $t+1$.

- Among candidate matches present in year $t+1$, set Flag 3 to 1 for firm IDs that achieve the highest rank.

If one, and only one, firm ID satisfies Flag $1=$ Flag $2=$ Flag $3=1$, we treat that firm as the true match and use it in our analysis. This three-flag method resolves about 1000 additional buyouts to a Census firm ID. Altogether, our three resolution methods yield about 2000 additional matched deals. This gives us the total sample of approximately 6000 matched buyout deals.

\section{Tracking Firms and Establishments after the Buyout}

As explained in the main text, we cannot always track target firms with confidence in the years after the buyout. Tracking difficulties can arise because (a) a target is broken into many pieces, some or all of which are re-sold to other firms, and (b) errors and ambiguities in Census data prevent us from following the firm with confidence after the buyout. Thus, our econometric analysis in Section III examines the sample of "Two-Year Continuers" that we track with confidence. Our concept of "Continuers" includes firms that die in the sense that all of its establishments in the buyout year $t$ cease to operate by $t+2$.

Tracking establishments in Census data is typically much easier than tracking firms. However, even establishments are challenging to track in certain limited circumstances. Every five years, the Census Bureau obtains a full list of establishments owned by multi-unit firms from the Economic Censuses. It obtains a full list of establishments owned by large multi-unit firms (250 or more employees before 2013) from the annual Company Organization Survey (COS). The COS also samples smaller multi-unit firms in a targeted manner based on information that they underwent rapid growth or organizational change. When this information is incomplete, Census 
may not promptly recognize new establishments operated by small, multi-unit firms in intercensal years. To address this matter, the LBD retimes the intercensal entry and exit of some establishments operated by small multi-unit firms. Still, the timing of M\&A activity for small multi-units not covered by the COS or other Census surveys exhibits some bunching in Economic Census years. We do not think this limited bunching is a serious concern for our analysis, in part because small units get little weight in our employment-weighted regressions. 


\section{Internet Appendix B: Empirical Methods and Identification Assumptions}

This appendix provides details about several aspects of our empirical methods. The first relates to how we track business outcomes over time. While we focus on firm-level outcomes, we exploit the establishment-level data in the LBD in several ways: to distinguish organic changes at the firm level from acquisitions and divestitures; to capture new facilities opened after the buyout; and to decompose firm-level employment changes into the gross job creation and destruction components associated with growing and shrinking establishments, respectively. The LBD's capacity to isolate each of these adjustment margins is one of its major strengths.

A second aspect relates to aggregation and the measurement of growth rates. Let $E_{i t}$ denote employment at establishment or firm $i$ in year $t$-i.e., the number of workers on payroll in the pay period covering March 12. We measure the employment growth rate of unit $i$ from $t-k$ to $t$ as $g_{i t, t-k}=\left(E_{i t}-E_{i, t-k}\right) / X_{i t, t-k}$, where $X_{i t, t-k}=0.5\left(E_{i t}+E_{i, t-k}\right)$. This growth rate measure is symmetric about zero and lies in the interval [-2,2], with endpoints corresponding to death and birth. ${ }^{27}$ Employment growth at higher levels of aggregation is then given by $g_{t, t-k}=$ $\sum_{i}\left(X_{i t, t-k} / X_{t, t-k}\right) g_{i t, t-k}$, where $X_{t, t-k}=\sum_{i} X_{i t, t-k}$. Using these formulas, we can easily and consistently aggregate from establishments to firms, from individual units to industries, and over time periods. This approach to growth rates and aggregation also works for gross job creation and destruction, job reallocation, and employment changes along particular dimensions such as acquisitions and divestitures or continuing establishments.

27 This growth rate measure has become standard in analyses of establishment and firm dynamics, because it shares some useful properties of log differences while also handling entry and exit. See Davis, Haltiwanger, and Schuh (1996) and Törnqvist, Vartia, and Vartia (1985). 
A third aspect relates to the selection of control units for comparison to buyout targets in our regression models. We need suitable control units because the distribution of PE buyouts across industries and business characteristics is not random. Target firms are larger and older than the average firm and disproportionately concentrated in manufacturing, information technology, accommodations, and food services (Davis et al., 2014). They also differ by deal type, as shown above. Moreover, growth and volatility vary greatly by firm size and age, and workplaces and technologies differ greatly by industry. ${ }^{28}$ Hence, we sort target firms into cells defined by industry, size, age, multi-unit status, and buyout year. We then identify all firms not backed by private equity that fall into the same cell as the given target firm(s), and treat those firms as control units for the target firm(s) in that cell. Specifically, we define our control cells as the full cross product of about 90 industries (at the three-digit NAICS level), ten firm size categories, six firm age categories, a dummy for firms with multiple establishments, and 32 distinct buyout years from 1980 to $2011 .^{29}$ This classification yields over 10,000 control cells per year. Of course, many cells are unpopulated, but the flexibility and richness of our approach to control units is clear.

Fourth, we estimate the effects of buyouts using a difference-in-difference approach. That is, we compare changes in jobs and productivity at target firms in the wake of buyouts to

\footnotetext{
${ }^{28}$ Much previous research highlights sharp differences in employment growth and the pace of job reallocation by firm size, firm age, and industry. See, for example, Davis, Haltiwanger, and Schuh (1996) and Haltiwanger, Jarmin, and Miranda (2013).

${ }^{29}$ We define industry for multi-unit firms based on the modal industry of their establishments, computed on an employment-weighted basis. Our firm size categories are 1-4, 5-9, 10-19, 20-49, $50-99,100-249$, 250-499, 500-999, 1000-2499, 2500-4999, 5000-9999, and 10000 or more employees. Our firm age categories are 0-5 years, 6-10, 11-15, 16-20, and 21 or more years. Following Davis et al. (2014), when a firm first appears in the LBD, we assign it the age of its oldest establishment. We then increment the firm's age by one year for each year it continues as a legal entity in the LBD. In this way, we avoid arbitrary increases or decreases in firm age due to the sale and purchase of establishments.
} 
contemporaneous changes at their matched control units. ${ }^{30}$ This approach, together with our control variables, facilitates an apples-to-apples comparison when estimating buyout effects.

A fifth aspect pertains to how we weight observations in the estimation. In this regard, we are mindful that buyout effects can vary with firm characteristics and economic conditions and by industry, deal type, and time period. Indeed, the main text documents material differences in the effects of buyouts on these dimensions. However, there is surely more heterogeneity in treatment effects than we can estimate with precision. Faced with this heterogeneity, our goal is to obtain a consistent estimate for the activity-weighted mean treatment effect on treated units under two common identification assumptions in regression studies of treatment effects:

- CMI (conditional mean independence): Conditional on controls and the treatment indicator, outcomes for treated and non-treated units are independently distributed within cells.

- SUTVA (stable unit treatment value): Treating one unit has no effect on the outcomes of other units. $^{31}$

To achieve our estimation goal, we adopt two principles in weighting the observations: ${ }^{32}$

- TS (target-share weighting): Weight each target (and each target cell) by its share of aggregate target activity, where "aggregate" refers to the sum over all buyouts in the regression sample.

- SCT (set control weights to targets): Set the sum of weights on controls in a given cell to the cell's target activity share.

${ }^{30}$ In Davis et al. (2014), we find that propensity score matching estimators yield very similar results. We stick with the control cell approach in this paper for simplicity.

${ }^{31}$ See Chapter 18 in Wooldridge (2002) for an extended discussion of CMI and SUTVA in panel regression studies of treatment effects.

32 Neither equal weighting nor simple activity weighting of regression observations recovers the average treatment effect of interest. 
To be precise, suppose we have two target firms in two separate control cells, and we are interested in target-control comparisons from $t$ to $t+k$. The targets have activity levels $X_{1, t+k, t}=$ $0.5\left(E_{1, t+k}+E_{1 t}\right)$ and $X_{2, t+k, t}=0.5\left(E_{2, t+k}+E_{2 t}\right)$. The first target's share of aggregate target activity is $\omega_{1, t+k, t} \equiv X_{1, t+k, t} /\left(X_{1, t+k, t}+X_{2, t+k, t}\right)$, and the second's share is $\omega_{2, t+k, t} \equiv$ $X_{2, t+k, t} /\left(X_{1, t+k, t}+X_{2, t+k, t}\right)$. Since each control cell has a single target, these are also the control cell weights. ${ }^{33}$ Principle SCT requires $\sum_{j}^{\mathbb{C}=1} \omega_{j, t+k, t}=\omega_{1, t+k, t}$ and $\sum_{j}^{\mathbb{C}=2} \omega_{j, t+k, t}=\omega_{2, t+k, t}$, where $\mathbb{C}$ indexes control cells, and $j$ indexes control units in the cell.

Principle TS helps recover an average treatment effect that reflects the distribution over cells of target activity levels. Principle SCT has a similar motivation. It also ensures that the influence of control units on the coefficient estimates for covariates reflects the distribution over cells of target activity levels. Principle SCT is silent on exactly how to set control unit weights within cells, as long as they sum to the cell's share of aggregate target employment. In practice, we weight each control unit in proportion to its share of employment among the control units in the cell. After obtaining these proportions, we rescale them to satisfy SCT. We experimented with other approaches to weighting control units that comply with SCT. In particular, we tried equal weights for all control units within a given cell. We also tried winsorizing the weights of very large control units before rescaling to comply with SCT. These alternative approaches to weighting control units led to results similar to the ones reported below. ${ }^{34}$

\footnotetext{
${ }^{33}$ Note that we define a unit's activity level as the average of its employment at the start and end of the time interval under consideration. This practice conforms to our overall approach to aggregation and growth rate measurement, as discussed above.

${ }^{34}$ A subtle issue with weighting had to do with divisional buyouts, where one unit is spun out of a larger entity. Here we use employment in the spun-out entity after the buyout transaction, not that of its pre-buyout corporate parent.
} 
Three concerns motivated our experimentation with alternative schemes that give less weight to larger control units, while still adhering to principle SCT. First, very large employment values for certain control units could reflect measurement error. This concern might apply to targets as well, but since our sample has only a few thousand targets, we scrutinize them carefully. We believe we have identified (and corrected) gross errors in target outcomes. A similarly careful approach for controls is infeasible, since there are so many of them. Second, it is often hard to fit very large firms into a particular industry category, even at the three-digit NAICS level. The classification challenges presented by such large firms raise concerns about the suitability of the treatment-control comparison. Third, the very largest control firms can be much larger than the corresponding target firm. The vast difference in size raises a different source of concern about the suitability of the treatment-control comparison. By applying equal weights to control units in a given cell or winsorizing the weights, we mitigate these concerns.

Recall that we aim to recover the average treatment effect on the treated (buyout) firms under CMI and SUTVA. A standard approach, which we took in Davis et al. (2014), is to fit a regression model with heterogeneous treatment effects, average over the treatment effect estimates, and compute the standard error for the average treatment effect by the delta method. (See Chapter 18 in Wooldridge, 2002.) Weighting principles TS and SCT afford a simpler econometric approach that recovers the average treatment effect of interest from a specification with a homogenous treatment effect. Under this simpler approach, we need not resort to the delta method to obtain standard errors. We can instead obtain them directly from the standard output for weighted least squares regressions in STATA and other widely used statistical packages. That is the approach we take in this paper. 


\section{Internet Appendix C: Creating the Private Equity Group-Transaction Sample}

This appendix describes how we supplemented our database to capture information about the PE groups (also referred to as general partners, or GPs) that sponsor buyouts.

We transformed our original data for present purposes from being at the buyout level (as in Tables 3 through 8 ) to being at the buyout-PE group level. Thus, a single buyout transaction identifier may have multiple entries (with the same CapitalIQ transaction identifier), if there is a "club" (or syndicated) transaction with participation by multiple PE groups. In the Capital IQ database, there are 9809 distinct transactions meeting our criteria. In $89 \%$ of the cases, we obtained at least minimal information (organization type and fundraising history) about at least one buyout group active in the transaction. Because some transactions involve multiple PE groups, there are 11,606 distinct observations of PE group-buyout pairs. The most-active PE groups in the sample by deal count include some of the largest and most recognizable PE organizations, as well as leading specialists in middle market deals. (As we document in Table 2, sample sizes shrink once these data are matched to the Census information.)

\section{PE Group Identifier}

We assigned each PE group an identification number. That was simple when the group began as and remained an independent entity. Cases involving a change in control (and sometimes a name change), often associated with an acquisition or spin-off, were more complex.

Where there was a spin-out, we considered the spun-out entity to be a new PE group (with a new identifier), unless we were highly confident that it encompassed essentially all the PE investment activity of the predecessor group. In the latter case, a group might change status over time: i.e., from part of a bank or a family office to independent. When an independent group was acquired by another group, it was subsumed into the acquiring group after the acquisition, and its 
investments assigned to the acquirer's identifier. In addition to relying on entries in Capital IQ (the "Firm Description" field, a text description of the firm's history, its investment profile, and more), Refinitiv Thomson One, and Preqin databases, we undertook extensive online research to make these determinations. We especially relied here on searches using Factiva and Lexis-Nexis for historical information that was not accessible through searches of the unrestricted Internet.

In many cases, it was helpful to use information about the year the organization was founded in these determinations. Capital IQ often reports the year founded, sometimes in the "Firm Description" field instead of the "Year Founded" field. In cases where this information was missing, we used the start dates reported in Preqin.

Three complexities, however, arose in the determination of founding dates:

- Firms spun off from another institution (typically a bank) sometimes recorded their start date as that of the spin-off, and other times when the predecessor group was established. We standardized these (to the extent possible) to the year the predecessor group was established within the old parent institution. If instead of the spin-off of a clearly delineated group within the old parent institution, the creation of the firm entailed the departure of a few individuals within a larger body, the date of the actual firm formation was used.

- Groups that were still parts of a parent institution sometimes used the year the first PE program was set up at the parent, the year the specific initiative was established, or the year the parent was established. We standardized these to the extent possible to the year the first PE program was set up at the parent institution. If we could not get a start date of the first PE program or the specific investing program's inception, we left this information blank. 
- Few corporations, family offices, and institutional investors disclosed when their private investment programs began, simply reporting when the overall entity was founded. If we could not get a date for the program's inception, we left this information blank.

\section{Type of Organization}

CapitalIQ was used to classify types of PE groups, particularly the fields "Primary Industry," "Institution Type," and "Firm Description." For groups whose status changed (e.g., due to an acquisition or divestiture), we used the information as it stood at the time of investment. Again, these changes were confirmed and precise dates identified using online searches. Where this information was incomplete, we supplemented it with online searches.

We used the following scheme to classify firms.

0- $\quad$ PE groups or diversified investors where private equity is an important component (e.g., Blackstone, Carlyle). This includes organizations with a "fundless" structure (e.g., who are investing off their balance sheet or on a "deal by deal" basis), as well as those who raised there last fund many years earlier.

1- Investment arms that are subsidiaries of other financial institutions, including investment/commercial banks, insurance companies, mutual funds, and brokerage houses, whether investing through funds or directly from these entities' balance sheets.

2- Investment arms that are subsidiaries of non-financial operating corporations, whether investing through funds or directly from these entities' balance sheets. In some cases, investment groups are identified by their largest holding, making them difficult to distinguish from operating companies. Other entities are unclear whether they are a business or investment company. A key test is whether there is a recognizable "core" business in a single or set of related industries. Berkshire Hathaway and GE are perhaps extreme cases. BH could be regarded as a 
(fundless) PE group, an insurer, or an operating company; we classified as a 0 . On the other hand, General Electric or Mitsubishi's various financing subsidiaries could be regarded for much of the period as a (funded or fundless) PE group, a financial services firm, or an operating company; we classified them as a 2. Because the sample is limited to PE buyout transactions (i.e., excluding traditional strategically motivated acquisitions), no transactions by Danaher Corp., one of the most active acquirers of U.S. manufacturing firms, are included in the database. Thus, the only corporate transactions are those where the firms are either (a) undertaking their own PE-type transactions, often through a financing arm, or (b) co-investing with a large limited partner.

3- Investment arms that are subsidiaries of institutional and family investors, such as pensions, sovereign wealth funds, university endowments, and the like, whether investing through funds or (more commonly) directly from these entities' balance sheets. Again, we also include coinvestments with PE groups; but as we point out elsewhere, the coverage of co-investment by CapitalIQ does not seem comprehensive and indeed biased (Fang, et al. [2015]).

4- $\quad$ Organizations with the bulk of their assets (90\%+) in debt, hedge, and real estate funds or who primary lend off their balance sheets (excluding commercial banks, who are included in 1), but who do some PE investing on the side. This category does not include diversified investment managers who also own some of these funds.

\section{Prior Fundraising}

Fundraising data was bulk-downloaded from Preqin. The Preqin firm names were matched to the firm names in the Capital IQ data. This matching, in many cases, took considerable background research using online sources, due to the plethora of groups with similar sounding names (e.g., Pine Brook, Pine Creek, Pine Street, Pine Tree Equity, Pine Tree Growth, and PineBridge, not to mention various variants of White Pine). 
Coverage of funds (amounts raised and performance) in Preqin is imperfect, particularly before 2000. We supplemented the Preqin information with fundraising data from Refinitiv Thomson One for those entities with no fundraising data in the relevant period. (Again, this took considerable research to resolve name matching.) In other cases, we found fundraising material online (e.g., state pension web sites) that summarized the timing and size of a group's funds.

We summed the count and size of the funds closed in the year between the deal year in the original data and four years before (t-4 to t), covering PE funds. All fund totals are expressed in millions of current U.S. dollars, converted from foreign currencies (if necessary) using the exchange rate at the mid-point of the year of the investment contained in the U.S. Federal Reserve Bank's H-10 series. We identified which funds to use based on the organization of the firm as of the time of the investment. Thus, for transactions in 2007 and before, we would look only at the funds raised by GSO Capital Partners. After its 2008 acquisition by Blackstone, we would compute the total raised by Blackstone (and GSO) in the five-year period.

We also created a normalized series: the funding divided by total funding raised at the beginning of the deal year in the original data and four years before ( $t-4$ to $t$ ). These fundraising totals were for the years from 2000 to 2013 from Preqin (for U.S. based buyout and balanced private equity funds only) and from 1980 to 1999 from Thomson Reuters (North American-based buyout, mezzanine and growth funds). ${ }^{35}$

\section{Prior Fund Performance}

For these firms, performance data (as of the end of 2019 or the closest date prior to this point) for any funds from years t-12 to t-5 were also collected. We captured funds for banks and

\footnotetext{
${ }^{35}$ For years before 1980, we assumed based on press accounts an annual fundraising rate of $\$ 100$ million per year in 1978 and 1979, and \$50 million per year in 1976 and 1977.
} 
corporations that raised funds under different divisions and programs (e.g., for General Electric, entities raising funds included GE Capital, GE Commercial Finance, and GE Holdings). These data were primarily taken from Preqin, but complemented with information from PitchBook and state public pension disclosure.

We focused on the performance of the most recent U.S. (or global) PE funds in that period with performance data and the two most recent funds. We looked at internal rate of return (IRR) and multiple of invested capital (MoIC), since this information was most readily available in Preqin. (Coverage of public market equivalents was much thinner.) In each case, we subtracted the benchmark performance calculated as the pooled IRR and weighted MoIC. The sources of the benchmark performance information were as follows:

- For vintages 1985,1987 to 1988 , and from 1990 to 2008: Preqin database, using data on North American buyout funds

- For vintages 1986 and 1989: Cambridge Associates via ThomsonOne, using data on US buyout and growth equity funds.

- For vintage years 1976 to 1984: Venture Economics, 1998 Investment Benchmark Reports, Newark, 1998, using data on US buyout funds (data on the 1976-83 period is consolidated in the report).

- For vintage years 1968 to 1975: Venture Economics, Venture Capital Performance 1989, Waltham, 1989, using data on all US private capital funds (data on the 1970-76 period is consolidated in the report).

In cases where we used multiple funds, we took a fund-weighted average of the fund net performance. Because this averaging process is more correct for TVPIs (an average of two IRRs 
may be quite different than the IRR of the combined cash flows), we focused in the TVPI measure in the paper.

This performance information was typically missing for groups that invested off their own balance sheet (which included many financial institutions, family offices, and corporations, and some private equity groups with fundless structures). In some cases, groups invested through both funds and their balance sheets, whether PE groups that have raised outside capital at the management company level (e.g., KKR) or more typically, banks and corporations. To cite one example, the amount raised through its funds was a small fraction of what GE invested, since most was done through its balance sheet. Unfortunately, there is no way to create a fund-like measure for balance sheet assets, since capital designated for investments is typically not segregated in financial reports. We thus computed the total for the formal funds.

We did a variety of diagnostic tests to verify the information and to catch potential errors. These exercises included:

- Looking at all PE investment entities with a start year before 1945. (Some entities did indeed start earlier, but we sought to be extra careful here.)

- Looking at PE investment entities with the same identification number but a different classification. (Again, due to spin-offs, some organizations did change status, but we were extremely careful and conservative here.)

- Looking at PE investment entities with the same identification number but a different start year. (Again, such cases could result as a result of a spin-off-see the rules delineated under Step 1-but we wanted to be sure.) 
- Looking at PE investment entities with the same identification number and transaction year, but a different number and volume of funds raised in the prior five years. (These were typically the result of miscoding organizations with complex organizational histories.)

- Looking at PE investment entities with the same identification number, but with substantial discrepancies in the number and volume of funds raised in the prior five years between adjacent years. (These were typically a consequence of miscoding organizations with complex organizational histories.) 


\section{Internet Appendix D: Additional Results}

Table D.1 tabulates the data presented in Figure 1 for three periods selected to highlight how PE deal flow sank during the financial crisis and recovered afterwards. Table D.2 follows Table 1 in the main text, except for using upper tercile splits rather than median splits for the GDP growth and credit spread variables. Table D.3 provides information about the distribution of PE buyouts by industry sector and deal type. It also uses the same sample as Figure 1.

In Table D.4, Panel A breaks down the overall employment change by establishment status. Here, "Continuers" refer to establishments that operate under ownership of the same firm (target or control) throughout the period from $t$ to $t+2$. Continuer employment at target firms shrinks by (a statistically insignificant) $1.5 \%$ relative to control counterparts in the two years after buyout. The rate of employment change at growing continuers is essentially identical for buyouts and controls, as indicated by the "Creation" results. In contrast, contracting continuers shrink more rapidly at targets, as indicated by the "Destruction" results. Target firms experience $4.0 \%$ larger employment losses from shuttered establishments ("Deaths") and 1.2\% greater employment gains due to new facilities ("Births"). They also add more jobs through acquisitions to the tune of $3.7 \%$ of base employment. All three of these differences are statistically significant. The difference in job changes from divestitures, however, is neither economically or statistically significant.

Because the regressions are employment weighted, we can sum the coefficients. Consider first the results for "Continuers" and "Deaths," which capture all employment changes for establishments owned and operated by targets and controls in the buyout year. Summing these two components yields a two-year employment growth rate differential of -5.6 percentage points $(-1.53-4.03)$. That is, establishments operated by target firms as of the buyout year shed $5.6 \%$ of employment relative to controls over the next two years, largely through establishment shutdowns. 
Factoring in the greater propensity of target firms to create more new jobs at new establishments adds 1.2 points to this sum. That yields a net differential of -4.4 percentage points for targets, the same as the organic growth change in the second row. Further factoring in the role of acquisitions and divestitures adds 3.0 points, yielding an overall buyout effect on firm-level employment of 1.4 percentage points over two years. The other panels in Table D.4 consider various results for job reallocation (overall and excess), compensation per worker, and labor productivity.

Table D.5 reports estimated buyout effects on employment by adjustment margin and buyout type.

Finally, Table D.6 provides evidence on the wage effects of PE buyouts using a larger, broader sample than previous studies. How buyouts affect wages has long been controversial. Critics argue that buyouts lead to lower wages, as formalized by Shleifer and Summers (1988). Indeed, Lichtenberg and Siegel (1990) find that buyouts lead to lower compensation for whitecollar workers. More recently, Agrawal and Tambe (2016) suggest that buyouts can enhance human capital in target firms, particularly by developing employee knowledge of information technology. Survey evidence in Gompers, Kaplan, and Mukharlyamov (2016) is consistent with this view.

Our wage measure in Table D.6 is the change from buyout year $t$ to $t+2$ in the firm's gross annual compensation per employee. ${ }^{36}$ The wage sample is smaller than in Panels A-C of Table 3

\footnotetext{
${ }^{36}$ Barth et al. (2014) provide a detailed description of the LBD wage measure: "The data follow the definition of salaries and wages used for calculating the federal withholding tax. They report the gross earnings paid in the calendar year to employees at the establishment prior to such deductions as employees' social security contributions, withholding taxes, group insurance premiums, union dues, and savings bonds. Included in gross earnings are all forms of compensation such as salaries, wages, commissions, dismissal pay, paid bonuses, vacation and sick leave pay, and the cash equivalent of compensation paid in kind. Salaries of officers of the establishment, if a corporation, are included. Payments to proprietors or partners, if an unincorporated concern, are excluded. Salaries and wages do not include supplementary labor
} 
for the same three reasons discussed in regard to productivity in the text. In addition, compensation data are unavailable for some firms in the LBD.

The first column in Table D.6, Panel A reports a statistically insignificant wage drop of $0.28 \%$ at target firms relative to controls over two years post buyout. Because we derive this estimate as a difference-in-difference, it nets out persistent target-control differences in workforce composition. However, it does not control for changes from the buyout year $t$ to $t+2$ in firm-level workforce composition. Establishment births, deaths, acquisitions, and divestitures are potentially important sources of such changes in firm-level workforce composition. ${ }^{37}$

Panel A suggests that buyout-induced wage effects also differ greatly by type. Compensation per worker rises by $11 \%$ in divisional targets relative to controls over two years post buyout, while falling by $6 \%$ in private-to-private deals. We find smaller, statistically insignificant wage declines for public-to-private and secondary deals. Large post-buyout wage gains at divisional targets may partly reflect what practitioners call "job title upgrading." When a corporate division becomes a new stand-alone firm, the divisional general manager (or his replacement) becomes CEO, the divisional controller becomes $\mathrm{CFO}$, and so on. The new titles and firm-wide responsibilities often come with (much) higher pay. The Carlyle Group's divisional buyout of DuPont Performance Coatings (renamed Axalta Coating Systems) in February 2013

costs such as employer's Social Security contributions and other legally required expenditures or payments for voluntary programs." Thus, our wage measure includes management compensation except for stock option grants, which are typically constructed to defer tax obligations until exercise or sale. Buyouts often tilt the compensation of senior management toward stock options (Leslie and Oyer, 2008), so we may slightly understate the true wage change at target firms.

37 Appendix Table D.4. explores these firm-level adjustment margins and show that they are especially active at target firms in the wake of buyout deals. 
offers a case in point. ${ }^{38}$ Panels $\mathrm{B}$ and $\mathrm{C}$ display the relationship between the differences in wage changes and economic conditions at and after the buyouts, and find few significant relationships.

Table D.1. Private Equity Deal Flow Before, During, and After the Financial Crisis. The table reports the quarterly flow of private equity buyouts, overall and by deal type, in selected periods. It also reports the average value of the credit spread in the closing month and the annual real GDP growth rate over the four quarters that end in the closing quarter. The table entries are tabulated from the data plotted in Figure 1.

\begin{tabular}{|c|c|c|c|c|c|}
\hline & $\begin{array}{c}\text { All PE } \\
\text { Buyouts }\end{array}$ & $\begin{array}{c}\text { Private } \\
\text { to } \\
\text { Private }\end{array}$ & $\begin{array}{c}\text { Public } \\
\text { to } \\
\text { Private }\end{array}$ & $\begin{array}{c}\text { Divisional } \\
\text { Sales }\end{array}$ & $\begin{array}{c}\text { Secondary } \\
\text { Sales }\end{array}$ \\
\hline $\begin{array}{c}\text { A. Pre-Crisis, January 2004 to } \\
\text { December 2007 }\end{array}$ & & & & & \\
\hline Buyouts Closed Per Quarter & 203 & 88 & 15 & 52 & 43 \\
\hline Average Credit Spread & $3.27 \%$ & & & & \\
\hline Average Real GDP Growth Rate & $2.85 \%$ & & & & \\
\hline $\begin{array}{c}\text { B. Crisis, October 2008 to June } \\
\text { 2010 }\end{array}$ & & & & & \\
\hline Buyouts Closed Per Quarter & 87 & 46 & 5 & 17 & \\
\hline Average Credit Spread & $11.79 \%$ & & & & \\
\hline Average Real GDP Growth Rate & $-1.40 \%$ & & & & \\
\hline $\begin{array}{c}\text { C. Post-Crisis, July 2010 to } \\
\text { December 2013 }\end{array}$ & & & & & \\
\hline Buyouts Closed Per Quarter & 133 & 58 & 9 & 17 & \\
\hline Average Credit Spread & $6.81 \%$ & & & & \\
\hline Average Real GDP Growth Rate & $1.97 \%$ & & & & \\
\hline
\end{tabular}

38 The top five personnel of Axalta received compensation in 2013 of $\$ 17.2$ million, including the aggregate fair value of stock option awards as of the grant date. While the reporting of option grants may differ for tax purposes (and hence in our data), even the total non-option compensation of the five individuals was $\$ 6.1$ million. We cannot directly observe the compensation of the top five employees of DuPont Performance Coatings in 2012, but web sites such as Glassdoor suggest that senior divisional managers at DuPont received contemporaneous compensation packages in the mid-six figures. See Axalta Coating Systems, Schedule 14A, March 23, 2015 and Lerner and Tuzikov (2018). Thus, the compensation of top Axalta personnel in 2013 was much greater than what they, or their counterparts, likely earned as senior divisional managers before the buyout. 
Table D.2. Market Conditions and Private Equity Buyout Frequency by Deal Type, Quarterly Data, 1980-2013, Upper Tercile Split Instead of the Median Split in Table 1 in the Main Text. We regress 100 times the natural log of the PE buyout count in quarter $t$ on deal-type indicators interacted with market conditions at buyout close (top panel) and over the following two years (bottom panel), while controlling for deal type and a linear time trend. The sample is the same as in Figure 1. To characterize contemporaneous market conditions for buyouts that close in quarter $t$, we consider whether the credit spread in $t$ is in the top tercile or not and whether real GDP growth from $t$-4 to $t$ is in the top tercile or not. Similarly, to characterize the evolution of market conditions over the next two years, we consider whether the change in the credit spread and real GDP from $t$ to $t+8$ are in the top tercile or not. After dropping quarter-type cells with no buyouts, each regression has 454 observations. $* * * \mathrm{p}<0.01, * * \mathrm{p}<0.05, * \mathrm{p}<0.1$.

Dependent Variable: $100 * \ln$ (type-specific buyout count in quarter $t$ )

\begin{tabular}{|c|c|c|c|c|c|c|}
\hline \multirow[b]{2}{*}{ Market Conditions } & \multicolumn{4}{|c|}{$\begin{array}{l}\text { Coefficient on Market Conditions (row) interacted } \\
\text { with Deal-Type Indicator (column) }\end{array}$} & \multirow{3}{*}{$\mathrm{R}^{\wedge} 2$} & \multirow{2}{*}{$\begin{array}{c}\text { Equality of } \\
\text { Coefficients } \\
\text { (p-value) }\end{array}$} \\
\hline & Private to Private & Public to Private & Divisional Sales & Secondary Sale & & \\
\hline \multicolumn{6}{|l|}{ A. At Buyout Close } & \\
\hline \multirow[t]{2}{*}{ High GDP Growth } & 17.4 & $75.0 * * *$ & $39.1 * * *$ & -11.4 & \multirow{4}{*}{0.74} & \\
\hline & {$[11.2]$} & {$[14.3]$} & {$[13.0]$} & [15.6] & & 0.000 \\
\hline \multirow[t]{2}{*}{ Wide Credit Spread } & $-40.5 * * *$ & $-37.4 * *$ & $-34.4^{*}$ & $-26.3^{* *}$ & & \\
\hline & {$[10.2]$} & {$[16.1]$} & [18.7] & [14.3] & & 0.000 \\
\hline \multicolumn{7}{|l|}{ B. Over Next 2 Years } \\
\hline \multirow[t]{2}{*}{ High GDP Growth } & -3.9 & 9.9 & 12.9 & $-40.9 * *$ & & \\
\hline & [12.4] & {$[14.2]$} & [13.9] & [17.3] & & 0.120 \\
\hline Widening Credit & & & & & 0.73 & \\
\hline \multirow[t]{2}{*}{ Spread } & $19.7^{*}$ & $61.5 * * *$ & $24.5^{*}$ & 22.7 & & \\
\hline & [11.3] & {$[14.8]$} & [14.1] & [14.8] & & 0.000 \\
\hline
\end{tabular}


Table D.3. Private Equity Buyouts by Industry Sector and Deal Type, 1980-2013. Each column reports the percentage breakdown of buyouts for the indicated deal type, using the Standard \& Poor's 2018 Global Industry Classification Standard (GICS). The sample is the same as in Figure 1.

\begin{tabular}{|c|c|c|c|c|c|c|}
\hline \multirow[b]{2}{*}{ Sector } & \multirow[b]{2}{*}{$\begin{array}{l}\text { GICS } \\
\text { code }\end{array}$} & \multicolumn{4}{|c|}{ Buyout Type } & \multirow[b]{2}{*}{ Total } \\
\hline & & $\begin{array}{c}\text { Private- } \\
\text { to- } \\
\text { Private }\end{array}$ & $\begin{array}{c}\text { Public-to- } \\
\text { Private }\end{array}$ & Divisional & Secondary & \\
\hline Energy & 10 & 2.9 & 2.2 & 2.6 & 2.2 & $2.6 \%$ \\
\hline Materials & 15 & 8.1 & 5.7 & 9.3 & 8.6 & $8.3 \%$ \\
\hline Industrials & 20 & 28.9 & 19.0 & 23.4 & 28.6 & $26.5 \%$ \\
\hline Consumer staples & 25 & 18.6 & 24.6 & 18.8 & 20.7 & $19.6 \%$ \\
\hline \multicolumn{7}{|l|}{ Consumer } \\
\hline Health care & 35 & 10.1 & 12.0 & 8.0 & 10.3 & $9.7 \%$ \\
\hline Financials & 40 & 3.9 & 4.7 & 4.7 & 2.7 & $3.9 \%$ \\
\hline \multicolumn{7}{|l|}{ Information } \\
\hline \multicolumn{7}{|l|}{ Communications } \\
\hline services & 50 & 7.2 & 7.5 & 8.1 & 7.4 & $7.5 \%$ \\
\hline Utilities & 55 & 0.6 & 1.0 & 2.1 & 0.8 & $1.1 \%$ \\
\hline \multirow[t]{2}{*}{ Real estate } & 60 & 0.8 & 3.1 & 1.3 & 0.2 & $1.0 \%$ \\
\hline & & $100.0 \%$ & $100.0 \%$ & $100.0 \%$ & $100.0 \%$ & $100.0 \%$ \\
\hline
\end{tabular}

Note: A test of the null hypothesis that the industry distribution of buyouts is independent of deal type yields a Pearson Chi-squared statistic of 260.7 with a p-value of 0.000 . 
Table D.4. Buyout Effects by Adjustment Margin at Target Relative to Control Firms. The sample contains matched two-year continuers that underwent private equity buyouts from 1980 to 2011 and control firms in the same cells defined by the full cross product of firm age, firm size, industry, multi-unit status and buyout year. Some firms serve as controls for more than one buyout type. Outcome measures are (approximate) percentage amounts from the buyout year $t$ to $t+2$, unless otherwise noted. All results in Panel A are expressed as percentages of firm-level base employment. Each reported effect is the coefficient estimate [standard error] on a buyout indicator in a weighted least-squares regression that includes a full set of cell-level fixed effects and controls for pre-buyout growth histories. A positive coefficient in each case indicates that activity on that dimension is greater for buyouts. See Section II in the main text for an explanation of how we weight observations. Results for "All Margins" include the contribution of post-buyout acquisitions and divestitures, while results for "Organic Margins" exclude them. Reallocation measures are computed from establishment-level employment changes at the firm. Huber-White robust standard errors in brackets. $* * * \mathrm{p}<0.01, * * \mathrm{p}<0.05, * \mathrm{p}<0.1$

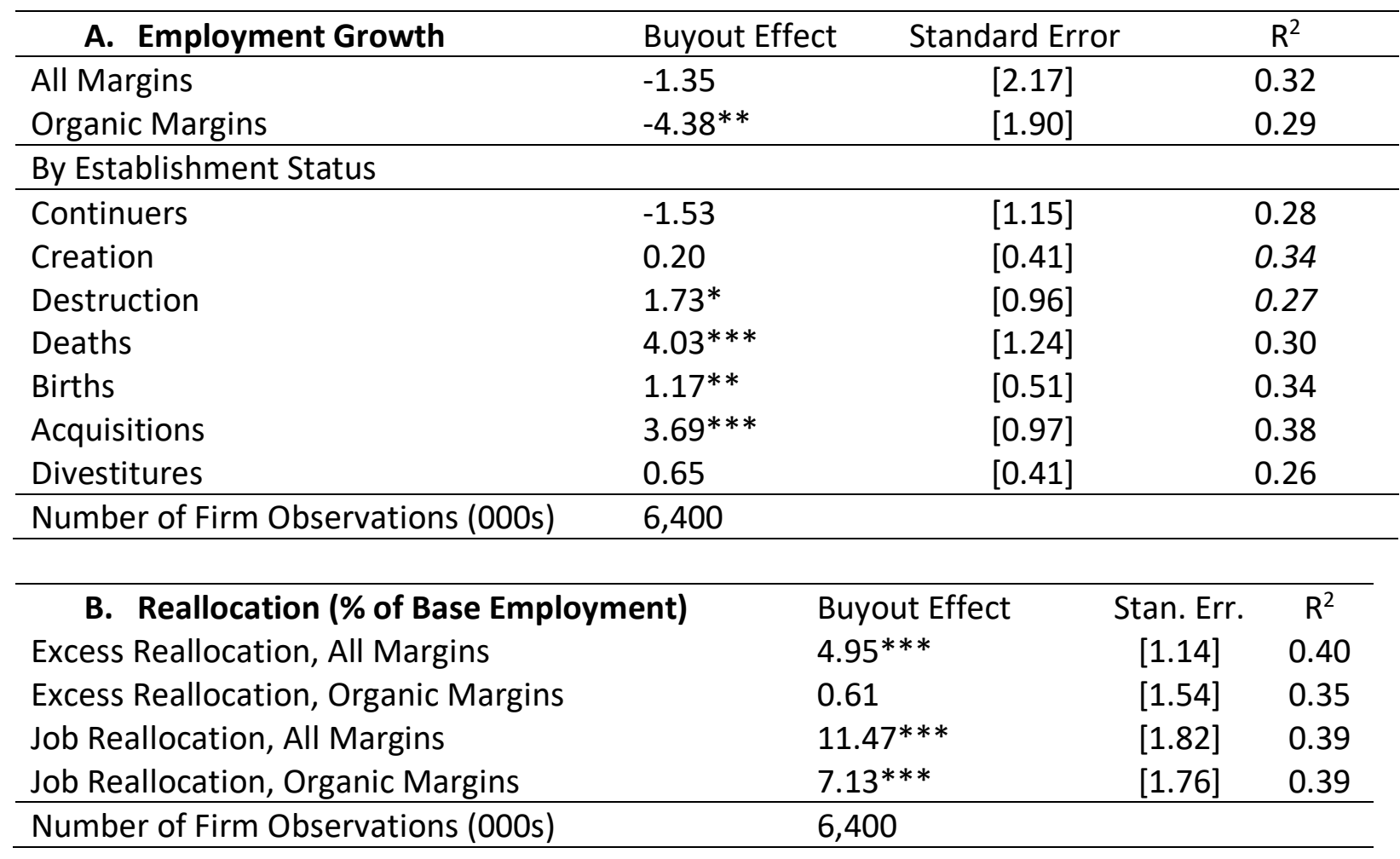

\section{Productivity Change at Targets Relative to Controls, and Separate Contributions of Revenue and Employment Changes}

\begin{tabular}{llcc}
\hline & Buyout Effect & Standard Error & $\mathrm{R}^{2}$ \\
Revenue Per Employee & $0.0752^{*}$ & {$[0.0406]$} & 0.47 \\
Revenue Contribution & 0.0618 & {$[0.0398]$} & 0.47 \\
Employment Contribution & -0.0133 & {$[0.0230]$} & 0.39 \\
Number of Firm Observations (000) & 911 & & \\
\hline
\end{tabular}


Table D.5. Buyout Effects on Employment by Adjustment Margin and Buyout Type. The sample contains matched two-year continuers that underwent private equity buyouts from 1980 to 2011 and control firms in the same cells defined by the full cross product of firm age, firm size, industry, multi-unit status and buyout year. Some firms serve as controls for more than one buyout type. Outcome measures are employment changes from the buyout year $t$ to $t+2$, expressed as a percentage of firm-level base employment. A positive coefficient in each case indicates that activity on that dimension is greater for buyouts. Each reported effect is the coefficient estimate [standard error] on a buyout indicator in a separate weighted least-squares regression that includes a full set of cell-level fixed effects and controls for pre-buyout growth histories. See Section II in the main text for an explanation of how we weight observations. Results for "All Margins" include the contribution of post-buyout acquisitions and divestitures, while results for "Organic Margins" exclude them. Reallocation measures are computed from establishment-level employment changes at the firm. Huber-White robust standard errors in brackets. $* * * \mathrm{p}<0.01, * * \mathrm{p}<0.05, * \mathrm{p}<0.1$

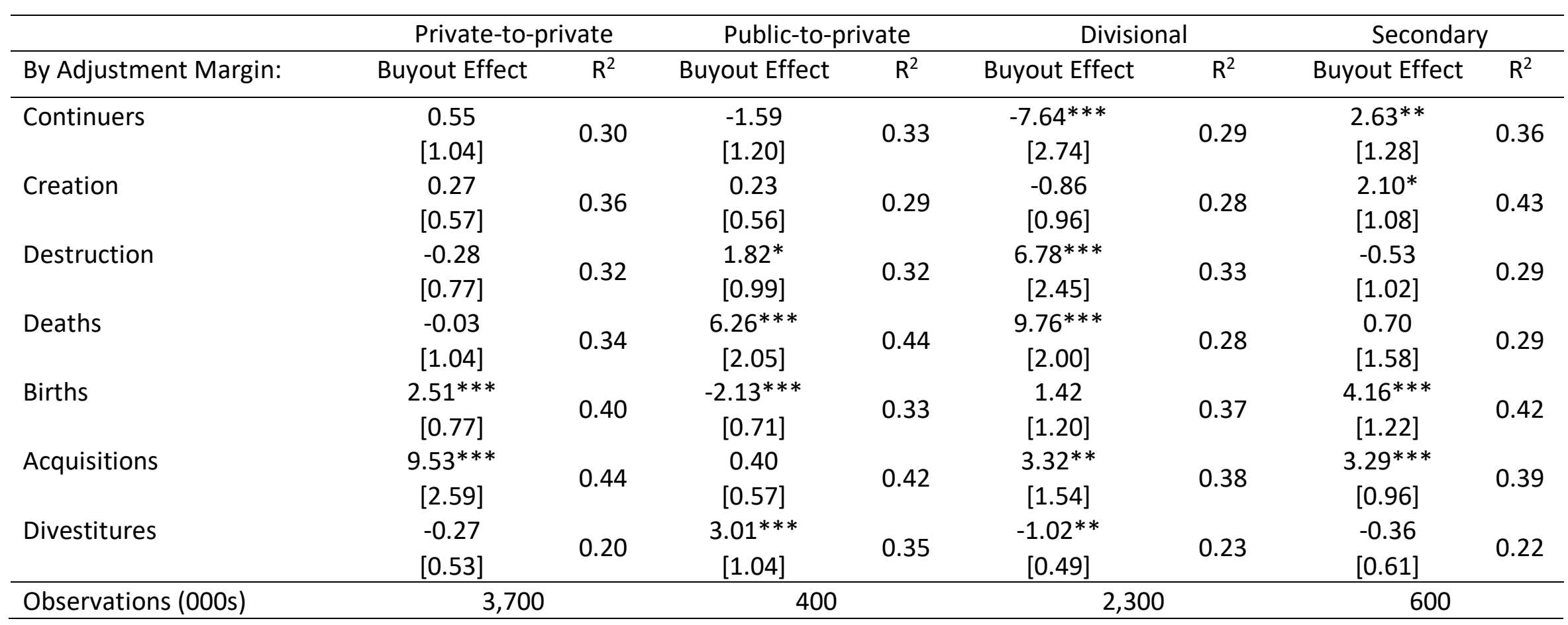


Table D.6. Buyout Effects on Wages by Establishment-Level Adjustment Margin. The table presents tables identical to those in the paper, but for wages. Panel A replicates Table 3; Panel B, Table 5; and Panel C, Tables 5 and 6 (first column only). See tables in the paper for more information.

Panel A: Estimated Buyout Effects.

\begin{tabular}{|c|c|c|c|c|c|c|c|c|c|c|c|}
\hline \multirow[b]{2}{*}{ Dependent Variable } & \multicolumn{2}{|c|}{ All Buyouts } & \multicolumn{2}{|c|}{ Private-to-private } & \multicolumn{2}{|c|}{ Public-to-private } & \multicolumn{2}{|c|}{ Divisional } & \multicolumn{2}{|c|}{ Secondary } & \multirow{2}{*}{$\begin{array}{l}\mathrm{p}-\text { Value } \\
\text { SUR test }\end{array}$} \\
\hline & Effect & $\mathrm{R}^{2}$ & Effect & $\mathrm{R}^{2}$ & Effect & $\mathrm{R}^{2}$ & Effect & $\mathrm{R}^{2}$ & Effect & $\mathrm{R}^{2}$ & \\
\hline $\begin{array}{c}\text { Annual Compensation } \\
\text { Per Employee }\end{array}$ & $\begin{array}{l}-0.28 \\
{[1.6]}\end{array}$ & 0.22 & $\begin{array}{l}-5.9 * \\
{[3.4]}\end{array}$ & 0.13 & $\begin{array}{l}-1.8 \\
{[1.6]}\end{array}$ & 0.81 & $\begin{array}{c}11.0 * * * \\
{[3.4]}\end{array}$ & 0.41 & $\begin{array}{l}-3.0 \\
{[2.5]}\end{array}$ & 0.37 & 0.040 \\
\hline Observations (000s) & \multicolumn{2}{|c|}{3,700} & \multicolumn{2}{|c|}{2,100} & \multicolumn{2}{|c|}{200} & \multicolumn{2}{|c|}{1,500} & \multicolumn{2}{|c|}{300} & \\
\hline
\end{tabular}

Panel B: How Buyout Effects Vary with Macroeconomic and Credit Conditions at the Close.

\begin{tabular}{cccc} 
& & \multicolumn{2}{c}{ Interaction Variable } \\
Dependent Variable & & Credit & GDP \\
& & Spread & Growth \\
& [St. Error] & {$[0.45]$} & {$[0.69]$} \\
& Unit S.D. Effect & 4.6 & -1.2 \\
\hline \multirow{2}{*}{ Annual Compensation } & Coefficient & 0.66 & -0.65 \\
Per Employee & [St. Error] & {$[0.62]$} & {$[0.78]$} \\
& Unit S.D. Effect & 2.0 & -1.1 \\
\hline
\end{tabular}

Panel C: How Buyout Effects Vary with the Credit Spread Change and GDP Growth in the Two Years after the Buyout.

\begin{tabular}{cccc} 
& & $\begin{array}{c}\text { Credit } \\
\text { Sepread }\end{array}$ & $\begin{array}{c}\text { GDP } \\
\text { Growth }\end{array}$ \\
\hline \multirow{2}{*}{ Annual Compensation } & Coefficient & $0.33^{*}$ & -0.24 \\
Per Employee & [St. Error] & {$[0.20]$} & {$[0.41]$} \\
& Unit S.D. Effect & 1.4 & -0.8 \\
\hline
\end{tabular}




\section{Additional References Not Cited in the Main Text}

Agrawal, Ashwini, and Prasanna Tambe, 2016. "Private equity and workers' career paths: The role of technological change." Review of Financial Studies, 29, 2455-2489.

Barth, Erling, Alex Bryson, James C. Davis, and Richard Freeman, 2014. "It's where you work: Increases in earnings dispersion across establishments and individuals in the U.S." National Bureau of Economic Research, Working paper no. 20447.

Davis, Steven J., John Haltiwanger, and Scott Schuh, 1996. Job Creation and Destruction. Cambridge, MA: The MIT Press.

Davis, Steven J., John Haltiwanger, Kyle Handley, Ron Jarmin, Josh Lerner, and Javier Miranda, 2018, "Private equity, jobs, and productivity: Reply to Ayash and Rastad.” Unpublished working paper, https://ssrn.com/abstract=3113272.

Fang, Lily, Victoria Ivashina and Josh Lerner, 2015. "The disintermediation of financial markets: Direct investing in private equity," Journal of Financial Economics, 116, no. 1, 160-178.

Haltiwanger, John, Ron S. Jarmin, and Javier Miranda, 2013. "Who creates jobs? Small vs. large vs. young." Review of Economics and Statistics, 95, 347-361.

Lerner, Josh, and Alexey Tuzikov, 2018. "The Carlyle Group and Axalta.” Harvard Business School Case 9-818-040.

Leslie, Phillip, and Paul Oyer, 2008. "Managerial incentives and value creation: Evidence from private equity." National Bureau of Economic Research, Working paper no. 14331, https://www.nber.org/papers/w14331.

Törnqvist, Leo, Pentti Vartia, and Yrjö Vartia, 1985. “How should relative change be measured?” American Statistician, 39, 43-46.

Wooldridge, Jeffrey M., 2002. Econometric Analysis of Cross Section and Panel Data. Cambridge: MIT Press. 